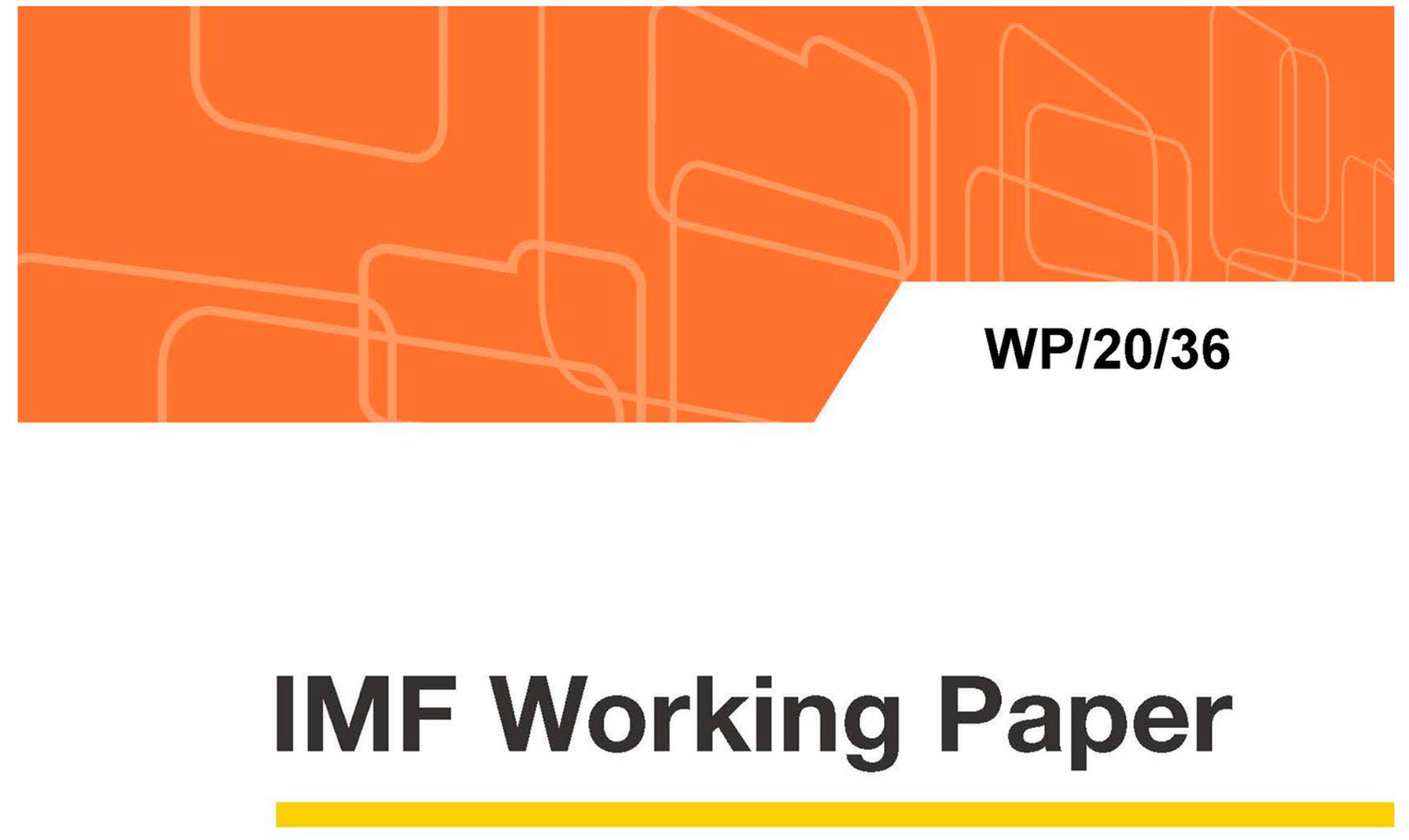

\title{
Markups, Quality, and Trade Costs
}

by Natalie Chen and Luciana Juvenal

IMF Working Papers describe research in progress by the author(s) and are published to elicit comments and to encourage debate. The views expressed in IMF Working Papers are those of the author(s) and do not necessarily represent the views of the IMF, its Executive Board, or IMF management. 


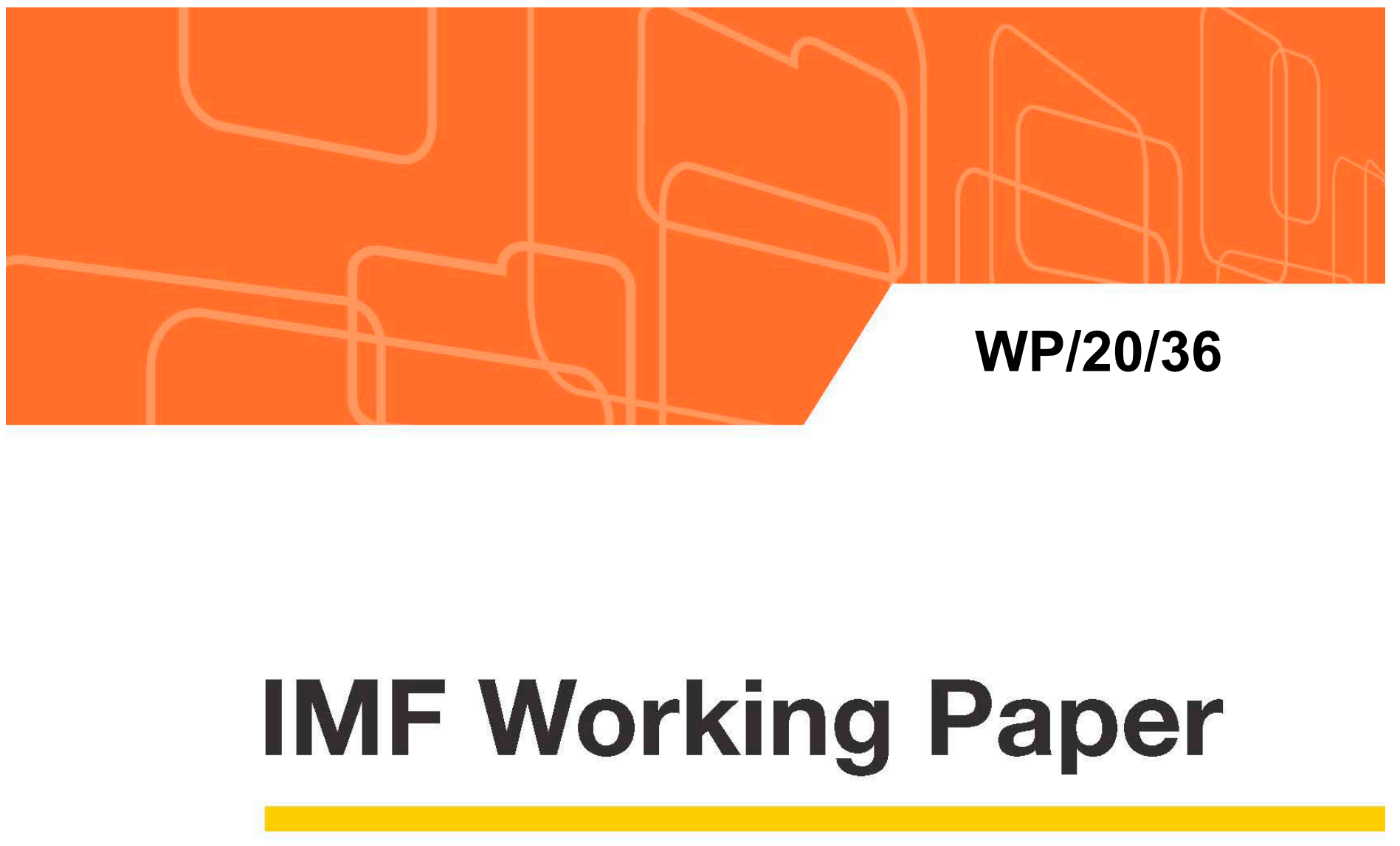

\section{Markups, Quality, and Trade Costs}

by Natalie Chen and Luciana Juvenal

IMF Working Papers describe research in progress by the author(s) and are published to elicit comments and to encourage debate. The views expressed in IMF Working Papers are those of the author(s) and do not necessarily represent the views of the IMF, its Executive Board, or IMF management. 


\title{
IMF Working Paper
}

\author{
Research Department \\ Markups, Quality, and Trade Costs* \\ Prepared by Natalie Chen and Luciana Juvenal
}

Authorized for distribution by Daniel Leigh

February 2020

\begin{abstract}
IMF Working Papers describe research in progress by the author(s) and are published to elicit comments and to encourage debate. The views expressed in IMF Working Papers are those of the author(s) and do not necessarily represent the views of the IMF, its Executive Board, or IMF management.
\end{abstract}

\begin{abstract}
We investigate theoretically and empirically how exporters adjust their markups across destinations depending on bilateral distance, tariffs, and the quality of their exports. Under the assumption that trade costs are both ad valorem and per unit, our model predicts that markups rise with distance and fall with tariffs, but these effects are heterogeneous and are smaller in magnitude for higher quality exports. We find strong support for the predictions of the model using a unique data set of Argentinean firm-level wine exports combined with experts wine ratings as a measure of quality.

JEL Classification Numbers: F12, F14, F31

Keywords: Distance, export unit values, heterogeneity, markups, quality, tariffs, trade costs.

Author’s E-Mail Address: n.a.chen@warwick.ac.uk, ljuvenal@imf.org.

*We thank the Federal Reserve Bank of St Louis and the International Monetary Fund for financial support. For helpful suggestions we thank Camila Casas, Rosario Crinò, Julien Martin, J. Peter Neary, Dennis Novy, Scott Orr, Frédéric Warzynski, and participants at the DIEW Workshop in Aarhus 2019, Rocky Mountain Empirical Trade Conference in Banff 2019, Royal Economic Society Annual Conference in Warwick 2019, the Bank of Italy, University College Dublin, and Oxford. Moreover, we are particularly grateful to Xiangjun Ma and Isabelle Méjean. The views expressed are those of the authors and do not necessarily reflect official positions of the International Monetary Fund.
\end{abstract}




\section{Introduction}

One robust finding in the empirical trade literature shows that exporters set higher Free on Board (FOB) export prices in more distant countries. This empirical regularity can be explained by several theoretical mechanisms. A first mechanism is a composition effect, also known as the Alchian and Allen (1964) effect, which arises due to the existence of per unit trade costs which lower the relative price, and increase the relative demand for higher quality goods in more distant countries. As higher quality goods are more expensive, firm-level prices increase with distance. A second mechanism is a selection effect which occurs if firms find it profitable to export higher quality varieties to more distant markets only, resulting in quality sorting. The exit of cheap and lower quality exports in more distant markets implies that, on average, export prices rise with distance. Lastly, firms may price discriminate and charge higher markups and therefore higher prices when exporting to more distant countries. ${ }^{1,2}$

Recent empirical work confirms that firm-level markups are indeed variable. For instance, they respond to trade liberalization (De Loecker, Goldberg, Khandelwal, and Pavcnik, 2016), exchange rate fluctuations (Berman, Martin, and Mayer, 2012), they vary with per capita income (Simonovska, 2015), and with firm-level characteristics (De Loecker and Warzynski, 2012). ${ }^{3}$ Surprisingly, there is no evidence on how firm-level markups vary across destinations depending on trade costs such as bilateral distance or tariffs. Nor is there any evidence on how product quality shapes the response of markups to changes in trade costs.

We fill these gaps by exploring theoretically and empirically how exporters adjust their markups across destinations depending on distance, ad valorem tariffs, and the quality of their exports. Our model shows that for a given quality, markups rise with distance and fall with tariffs. These effects, however, are smaller in magnitude for higher quality exports. We find strong support for the predictions of the model using a unique data set of Argentinean firm-level wine exports combined with experts wine ratings as a measure of quality (Chen and Juvenal, 2016, 2018; Crozet, Head, and Mayer, 2012). Our paper is thus the first to establish that distance and tariffs impact markups across international markets, and that their effects are heterogeneous across quality levels.

Our first contribution is to model theoretically the effects of trade costs on the pricing strategies of exporters across destinations. We extend the monopolistic competition model of Martin (2012) where exporters maximize profits subject to a CES demand in each destination country. Trade costs are

\footnotetext{
${ }^{1}$ For evidence on Alchian and Allen (1964), see Emlinger and Lamani (2017), Hummels and Skiba (2004), and Takechi (2015). On selection, see Baldwin and Harrigan (2011), Bastos and Silva (2010), Crozet, Head, and Mayer (2012), Harrigan, Ma, and Shlychkov (2015), and Johnson (2012). See, also, Görg, Halpern, and Muraközy (2017), Lugovskyy and Skiba (2015, 2016), Manova and Zhang (2012), and Martin (2012). An older literature on spatial price discrimination studies how firms adjust their markups depending on the distance to the buyer (Greenhut, Ohta, and Sailors, 1985; Hoover, 1937). "Dumping" and "reverse dumping" arise if firms charge lower or higher markups in more distant countries.

${ }^{2}$ Composition is a demand-side effect, while selection and price discrimination are supply-side mechanisms. On the supply side, firms may also upgrade their quality for more distant countries (Martin, 2012). Higher quality goods would then be disproportionately shipped at longer distances, resulting in firm-level prices increasing with distance.

${ }^{3}$ See inter alia Amiti, Itskhoki, and Konings (2014, 2019), Atkin and Donaldson (2015), Bellone, Musso, Nesta, and Warzynski (2014), Chen, Imbs, and Scott (2009), Chen and Juvenal (2016, 2018), and Fitzgerald and Haller (2014).
} 
both ad valorem and per unit, and the introduction of per unit trade costs generates variable markups that depend on trade costs (Crozet et al., 2012; Irarrazabal, Moxnes, and Opromolla, 2015). ${ }^{4}$ The model shows that for a given quality, export prices and markups increase with per unit trade costs, and therefore with distance. ${ }^{5}$ It also shows that prices and markups fall with ad valorem trade costs, and therefore with ad valorem tariffs. As we assume that producing a higher quality entails higher marginal costs, the model further predicts that the effects of trade costs (i.e., distance and tariffs) on prices and markups are heterogeneous and are smaller in magnitude for higher quality exports.

Our predictions are driven by the introduction of per unit trade costs in the model as the latter generate an elasticity of demand to the FOB price that depends on trade costs and quality (Crozet et al., 2012; Irarrazabal et al., 2015; Martin, 2012). Specifically, the demand elasticity falls with per unit costs, and therefore with distance, but it increases with ad valorem costs such as tariffs, especially for lower quality exports. To compensate for the lower demand they face due to higher trade costs, exporters thus find it profitable to raise their prices in more distant markets, to lower them in high-tariff countries, and to a larger extent for lower quality exports. Notably, these predictions are not specific to our CES framework and we show that they continue to hold with alternative demand systems.

Our second contribution is to investigate empirically the effects of trade costs on the prices and markups of exports differentiated by quality. Our firm-level trade data set reports, for each export transaction between 2002 and 2009, the name of the exporting firm, the country of destination, the date of shipment, the packaging type, the FOB value (in US dollars) and the volume (in liters) of each wine exported. A crucial feature of our data set is that exports are reported at the individual product level as each wine is identified according to its name, grape (Chardonnay, Malbec, etc.), type (white, red, or rosé), and vintage year. This level of detail is unique given that trade statistics are generally reported for product categories defined at the Combined Nomenclature (CN) or Harmonized System (HS) levels only (Bastos and Silva, 2010; Görg, Halpern, and Muraközy, 2017; Harrigan, Ma, and Shlychkov, 2015; Manova and Zhang, 2012; Martin, 2012).

We rely on the value and the volume exported at the firm-product-destination-time level to compute FOB unit values as a proxy for export prices. Our unit values can plausibly be interpreted as prices as they are defined at the individual product level. To measure the quality of each wine at the namegrape-type-vintage year level, we rely on two well-known experts wine ratings, the Wine Spectator and Robert Parker (Chen and Juvenal, 2016, 2018). ${ }^{6}$ Once we match the unit values from the customs

\footnotetext{
${ }^{4}$ Ad valorem (iceberg, or multiplicative) trade costs are applied as a percentage of the producer price per unit traded, while per unit (additive, or specific) trade costs are defined as a constant cost per unit traded.

${ }^{5}$ Per unit costs rise with distance as they vary with origin and destination (Irarrazabal, Moxnes, and Opromolla, 2015).

${ }^{6}$ A large body of theoretical and empirical work shows that quality plays a key role as a determinant of global trade flows and prices (Feenstra and Romalis, 2014; Hallak, 2006; Hummels and Klenow, 2005; Hummels and Skiba, 2004; Schott, 2004). As quality is unobserved, trade unit values are often used as a proxy. Recently, some papers have exploited direct measures of product quality. Atkin, Khandelwal, and Osman (2017) use artisan assessments for Egyptian rugs. Chen and Juvenal $(2016,2018)$ use the same quality ratings for Argentinean wines as in this paper. Crozet et al. (2012) use quality scores for Champagne. Emlinger and Lamani (2017) rely on the amount of time the eau-de-vie used to produce Cognac spends in oak. Medina (2018) identifies the quality of apparel products based on their composition of primary materials. Other papers derive alternative measures of quality. Khandelwal (2010) compares exporters' market shares conditional on price to infer export quality. Piveteau and Smagghue (2019) estimate quality using trade data.
} 
data set with the quality ratings of the Wine Spectator which has the largest coverage of Argentinean wines, we observe 237 multi-product wine producers shipping 8,361 different wines with heterogeneous levels of quality. Our focus on wine producers implies that each wine is exported by a single firm only.

For our purposes, our data set offers several advantages. First, thanks to the granularity of our data, we can compare the prices of a given product exported by a single producer at a given point in time across destinations, holding quality constant. Second, we can identify the variation in markups by controlling for product-time fixed effects. As the product-time fixed effects enable us to isolate the variation in unit values across destinations for a given exporter and a given product at each point in time, they control for selection and composition effects across products within firms. And since product-specific marginal costs do not vary across destinations, the variation in unit values across markets captures the variation in markups. Third, in contrast to papers relying on unit values as a proxy for quality (Hallak, 2006; Hummels and Skiba, 2004; Kugler and Verhoogen, 2012), our external measure of quality allows us to explore how firms set their prices and markups across destinations depending on the quality they export. Fourth, exports are reported FOB and therefore measure the revenue received by exporters at the border, excluding transport costs, tariffs, and distribution costs in the importing country. Fifth, shipping fees for wine are based on the volume exported, while insurance fees or tariffs are proportional to value (Crozet et al., 2012). Consistent with the assumptions of our model, wine exports are thus subject to both per unit and ad valorem trade costs (we provide evidence that both types of trade costs are indeed pervasive in our data). ${ }^{7}$

Our main results can be summarized as follows. First, we show that firm-level export prices increase with distance and fall with tariffs. On average, a doubling of distance increases prices by 2.74 percent, while a doubling of tariffs reduces them by 1.37 percent. Second, we demonstrate that the effects of distance and tariffs on prices survive the inclusion of product-time fixed effects. This specification therefore provides direct evidence that exporters raise their markups in more distant markets, and lower them in high-tariff countries. On average, a doubling of distance increases markups by 1.47 percent, while a doubling of tariffs reduces them by 1.04 percent. Variable markups thus explain around half of the impact of distance, and three-quarters of the effect of tariffs on the variation in within firm prices across destinations, the rest being due to selection or composition effects across products within firms. Third, we show that the elasticities of markups with respect to distance and tariffs are smaller in magnitude for the wines of higher quality. At the $5^{\text {th }}$ percentile of the quality distribution, markups rise by 3.67 percent and fall by 2.73 percent in response to a doubling of distance and tariffs, respectively, while no changes are detected at the $95^{\text {th }}$ percentile. Notably, our results continue to hold once we control for alternative mechanisms such as the heterogeneous pricing-to-market behavior of exporters or the extent of competition that each quality segment faces in foreign markets. They also remain robust to a whole battery of sensitivity tests, and in particular to using alternative measures of quality, different samples, and to instrumenting tariffs and quality.

\footnotetext{
${ }^{7}$ See Bosker and Buringh (2019), Daudin, Héricourt, and Patureau (2018), Hummels and Skiba (2004), Irarrazabal et al. (2015), Lashkaripour (2017), Lugovskyy and Skiba (2015), and Takechi (2015) for evidence on per unit trade costs.
} 
We then provide extensions to our main specifications. We show that the heterogeneous effects of trade costs on markups are stronger for exports to richer destinations. They are also predominantly driven by the higher quality firms, the larger firms, and the exporters who own a large share of the export market. As these high performance firms tend to charge higher markups, they are better able to adjust them across countries and quality levels in response to changes in trade costs. Next, using data on the universe of Argentinean firm-level manufacturing exports, we extend our analysis to industries other than wine. As quality is unobserved, we estimate the quality of each 8-digit HS-level product exported by each firm to each country in each time period (Khandelwal, 2010). The level of disaggregation of the data (at the HS level) prevents us from identifying the variation in markups, but we find that trade costs have heterogeneous effects on export prices differentiated by quality. Finally, we derive the predictions of our model for the effects of distance and tariffs on export volumes across quality levels, and we provide evidence that those predictions hold in our data set of wine exports.

Our results are important for several reasons. First, they provide strong evidence that the variation in firm-level export prices across markets is not only driven by quality differences but also by markup variation conditional on quality. Due to market power, firms thus price discriminate across destinations. But they also price discriminate more aggressively for lower quality exports. Second, as the markup of a given product with a given quality varies across export markets depending on distance and tariffs, we conclude that trade costs play a key role in generating deviations from the Law of One Price. Trade costs thus matter in explaining the degree of international market segmentation. Lastly, as our results are mainly driven by the high performance firms that contribute to the bulk of aggregate exports, we expect our findings to matter in explaining aggregate export prices and markups.

The remainder of the paper is organized as follows. Section 2 presents the model. Section 3 describes the firm-level exports data, quality ratings, macroeconomic indicators, and provides descriptive statistics. Section 4 presents the empirical methodology and our main results. Section 5 discusses extensions. Section 6 offers robustness checks and Section 7 concludes.

The appendix provides additional results. Appendix A shows that both per unit and ad valorem trade costs are present in our data. Appendix B discusses the predictions of our model using alternative demand systems. Appendix $\mathrm{C}$ examines how the elasticity of demand to the FOB price varies with trade costs and quality. Appendix D controls for selection bias across firms. Appendix E explains the estimation of quality for manufacturing exports. The sensitivity tests are reported in Appendix F.

\section{The Model}

We extend the monopolistic competition model of Martin (2012) where exporters maximize profits subject to a CES demand in each destination country. ${ }^{8}$ Trade costs are both ad valorem and per unit, and the introduction of per unit trade costs generates variable markups that depend on trade costs. ${ }^{9}$

\footnotetext{
${ }^{8}$ The theoretical model is available in the Martin (2010) working paper.

${ }^{9}$ In many models, including perfect competition models such as Eaton and Kortum (2002), or monopolistic competition models like Krugman (1980) or Melitz (2003), markups do not vary with country-level characteristics such as trade costs.
} 
The model shows that for a given quality, export prices and markups rise with per unit costs (distance), and fall with ad valorem costs (tariffs). ${ }^{10}$ Quality is exogenous, but producing a higher quality entails higher marginal costs as it requires sophisticated inputs, skilled workers, and specialized equipment which are expensive. The effects of trade costs on prices and markups are hence heterogeneous and are smaller in magnitude for higher quality exports. For simplicity we assume that firms produce a single good, but we extend the framework to multi-product firms in the empirical analysis.

\subsection{Setup}

Researchers typically model trade costs as ad valorem such that more expensive products are more costly to trade. As in Martin (2012) we instead assume that trade costs $t_{i j}$ have the following structure:

$$
t_{i j}=p_{i j}^{c i f}-p_{i j}^{f o b}=\left(\tau_{i j}-1\right) p_{i j}^{f o b}+T_{i j}
$$

where $p_{i j}^{c i f}$ and $p_{i j}^{f o b}$ are the Cost, Insurance, and Freight (CIF) and FOB prices of a monopolistically competitive firm $i$ exporting to country $j$, and $\tau_{i j}$ and $T_{i j}$ are the ad valorem and per unit components of trade costs, respectively. Trade costs are ad valorem only if $T_{i j}$ is zero, while they are per unit only if $\tau_{i j}$ is equal to one. As long as $T_{i j}$ is positive, trade costs are less than proportional to the FOB price.

The relationship between the CIF and FOB prices can be expressed as:

$$
p_{i j}^{c i f}\left(\tau_{i j}, T_{i j}, c_{i}(\theta)\right)=\tau_{i j} p_{i j}^{f o b}\left(\tau_{i j}, T_{i j}, c_{i}(\theta)\right)+T_{i j}
$$

where $c_{i}(\theta)$ is the marginal cost of firm $i$ which increases with quality $\theta$. Producing a higher quality entails higher marginal costs because it requires higher quality and therefore more expensive inputs (Crinò and Epifani, 2012; Feenstra and Romalis, 2014; Johnson, 2012; Kugler and Verhoogen, 2012; Manova and Zhang, 2012; Verhoogen, 2008). ${ }^{11}$

When exporting to country $j$, firm $i$ maximizes profits $\pi_{i j}$ :

$$
\pi_{i j}=\left[p_{i j}^{f o b}-c_{i}(\theta)\right] q_{i j}=\left[\left(\frac{p_{i j}^{c i f}-T_{i j}}{\tau_{i j}}\right)-c_{i}(\theta)\right] q_{i j},
$$

where $q_{i j}$ is the quantity sold by firm $i$ in market $j$ (which depends on $p_{i j}^{\text {cif }}$ ).

The representative consumer in destination country $j$ has preferences over the consumption of a continuum of differentiated varieties $\varphi$ given by:

$$
U\left(q_{i j}\right)=\left[\int \theta(\varphi)^{\frac{\sigma-1}{\sigma}} q_{i j}(\varphi)^{\frac{\sigma-1}{\sigma}} d \varphi\right]^{\frac{\sigma}{\sigma-1}},
$$

\footnotetext{
${ }^{10}$ Some models yield predictions for the effects of distance and tariffs on export prices while assuming that markups are invariant to trade costs. See Baldwin and Harrigan (2011), Fajgelbaum, Grossman, and Helpman (2011), Hummels and Skiba (2004), Johnson (2012), and Lugovskyy and Skiba (2015, 2016).

${ }^{11}$ For evidence that producing higher quality wines entails higher marginal costs, see Chen and Juvenal (2016). For instance, the oak barrels in which higher quality wines mature are more costly than stainless-steel tanks.
} 
where $\sigma>1$ is the elasticity of substitution between varieties. The set of available varieties is . Quality captures any intrinsic characteristic or taste preference that makes a variety more appealing for a consumer given its price. Therefore, consumers love variety, but also quality.

The inverse CES demand faced by firm $i$ in country $j$ is (Krugman, 1980; Melitz, 2003):

$$
p_{i j}^{c i f}=\kappa_{j} q_{i j}^{-\frac{1}{\sigma}} \theta^{\frac{\sigma-1}{\sigma}}
$$

where $\kappa_{j}$ is a positive parameter (exogenous to the firm) which is a function of the size and price index of the destination country. A higher quality $\theta$ shifts up the demand curve faced by the firm.

When firm $i$ maximizes profits in (3) subject to the demand in (5), the first order condition is:

$$
p_{i j}^{c i f}=\frac{\sigma}{\sigma-1}\left(T_{i j}+\tau_{i j} c_{i}(\theta)\right) .
$$

This yields the FOB price:

$$
p_{i j}^{f o b}=\frac{1}{\sigma-1}\left(\frac{T_{i j}}{\tau_{i j}}+\sigma c_{i}(\theta)\right),
$$

and the corresponding markup (Melitz and Ottaviano, 2008):

$$
\mu_{i j}^{f o b}=p_{i j}^{f o b}-c_{i}(\theta)=\frac{1}{\sigma-1}\left(\frac{T_{i j}}{\tau_{i j}}+c_{i}(\theta)\right)
$$

As producing a higher quality entails higher marginal costs, a higher quality sells at a higher price with a higher markup. In the standard case where trade costs are ad valorem only (i.e., $T_{i j}=0$ ), the FOB price and markup do not depend on trade costs. Instead, if trade costs are also per unit, the FOB price and markup depend positively on per unit costs $T_{i j}$, and negatively on ad valorem $\operatorname{costs} \tau_{i j}$. If trade costs are per unit only (i.e., $\tau_{i j}=1$ ), the FOB price and markup increase with trade costs.

\section{$2.2 \quad$ Trade Costs and Quality}

We assume that $T_{i j}$ increases with distance while $\tau_{i j}$ is independent of distance but varies with ad valorem tariffs (Hummels and Skiba, 2004; Irarrazabal et al., 2015; Lugovskyy and Skiba, 2015). The elasticities of the FOB price and markup with respect to $T_{i j}$ and $\tau_{i j}$ can therefore be interpreted as elasticities with respect to distance and tariffs, respectively. ${ }^{12}$ We calculate those elasticities and we show how they vary with export quality.

In our model, the introduction of per unit trade costs is crucial for our predictions. In Appendix A we replicate estimations from the literature to demonstrate that both per unit and ad valorem trade

\footnotetext{
${ }^{12}$ Assuming that distance only increases per unit trade costs, Irarrazabal et al. (2015) estimate that the elasticity of $T_{i j} / \tau_{i j}$ with respect to distance is equal to 0.23 . Some papers instead assume that distance increases both per unit and ad valorem trade costs but that the effect of distance is larger for per unit costs such that $T_{i j} / \tau_{i j}$ rises with distance (Crozet et al., 2012; Feenstra and Romalis, 2014; Martin, 2012; Takechi, 2015). In our model, our predictions remain the same whether we derive the elasticities of prices and markups with respect to $T_{i j} / \tau_{i j}$ or $T_{i j}$.
} 
costs matter in our data. We also show that trade costs become more per unit than ad valorem as distance increases.

Per Unit Trade Costs Using equations (7) and (8), we derive the elasticities of the FOB price and markup with respect to $T_{i j}$ :

$$
\begin{aligned}
\epsilon_{T}^{p^{f o b}} & =\frac{1}{\left(1+\frac{\sigma c_{i}(\theta)}{T_{i j} / \tau_{i j}}\right)}>0, \\
\epsilon_{T}^{\mu^{f o b}} & =\frac{1}{\left(1+\frac{c_{i}(\theta)}{T_{i j} / \tau_{i j}}\right)}>0 .
\end{aligned}
$$

The price and markup increase with per unit trade costs, and therefore with distance, but as marginal costs increase with quality (i.e., $c_{i}^{\prime}(\theta)>0$ ), the magnitude of the two elasticities falls with quality.

Prediction 1 The elasticities of the FOB price and markup with respect to bilateral distance are positive, and their magnitude decreases with quality.

From an empirical point of view, Prediction 1 implies that in regressions that explain FOB prices or markups, we expect the coefficient on distance to be positive, and the coefficient on the interaction between distance and quality to be negative.

Ad Valorem Trade Costs The elasticities of the FOB price and markup with respect to $\tau_{i j}$ are:

$$
\begin{aligned}
\epsilon_{\tau}^{p^{f o b}} & =\frac{-1}{\left(1+\frac{\sigma c_{i}(\theta)}{T_{i j} / \tau_{i j}}\right)}<0, \\
\epsilon_{\tau}^{\mu^{f o b}} & =\frac{-1}{\left(1+\frac{c_{i}(\theta)}{T_{i j} / \tau_{i j}}\right)}<0 .
\end{aligned}
$$

The price and markup decrease with ad valorem trade costs, and therefore with tariffs, but as marginal costs increase with quality the magnitude of the two elasticities in (11) and (12) falls with quality.

Prediction 2 The elasticities of the FOB price and markup with respect to ad valorem tariffs are negative, and their magnitude decreases with quality.

When explaining FOB prices or markups, Prediction 2 implies that the coefficient on tariffs should be negative, and the coefficient on the interaction between tariffs and quality should be positive.

Crozet et al. (2012), Irarrazabal et al. (2015), and Martin (2012) also show that the FOB price (and markup) rises with per unit trade costs (and therefore with distance) and falls with ad valorem costs (such as tariffs). The prediction that the magnitude of the elasticities of the price and markup with respect to distance and tariffs falls with quality is, instead, novel. ${ }^{13}$

\footnotetext{
${ }^{13}$ Crozet et al. (2012) derive the elasticity of the FOB price with respect to quality and show that it falls with distance.
} 


\subsection{Mechanisms}

Our predictions are driven by the introduction of per unit trade costs in the model as the latter generate an elasticity of demand to the FOB price that depends on trade costs and quality (Crozet et al., 2012; Irarrazabal et al., 2015; Martin, 2012). The elasticity of demand to the FOB price $\epsilon^{f o b}$ is given by:

$$
\epsilon^{f o b}=\frac{\epsilon^{c i f}}{\left(1+\frac{T_{i j}}{\tau_{i j} p_{i j}^{f o b}}\right)}=\frac{-\sigma}{\left(1+\frac{1}{\left(\frac{\sigma}{\sigma-1}\right)\left[\frac{1}{\sigma}+\frac{\tau_{i j}}{T_{i j}}\left(\frac{\sigma}{\sigma-1}\right) c_{i}(\theta)\right]}\right)}
$$

where $\epsilon^{c i f}$ is the elasticity of demand to the CIF price which is equal to $-\sigma$. If trade costs are ad valorem only $\left(T_{i j}=0\right)$, the elasticities of demand to the FOB and to the CIF price are identical.

If trade costs are also per unit, the elasticity of $\epsilon^{f o b}$ with respect to per unit trade costs (i.e., distance) is negative. Moreover, it increases with the FOB price, and therefore with marginal costs $c_{i}(\theta)$ and quality. As the demand in more distant markets is less elastic to changes in the FOB price, exporters find it profitable to raise their prices to compensate for the lower demand they face due to higher transport costs (as foreign demand falls with the CIF price which depends on per unit trade costs, see equations 5 and 6). But firms raise their prices less for higher quality exports.

Instead, the elasticity of $\epsilon^{f o b}$ with respect to ad valorem trade costs (i.e., tariffs) is positive, and it falls with the FOB price and quality. The demand faced by exporters in countries with higher tariffs is therefore more elastic to changes in the FOB price. To compensate for the lower demand they face due to higher tariffs (as tariffs raise the CIF price which in turn lowers foreign demand), firms reduce their prices, but they reduce them less for higher quality exports. ${ }^{14}$

\subsection{Alternative Demand Systems}

The predictions of our model are driven by two mechanisms: (1) the elasticity of $\epsilon^{f o b}$ with respect to per unit trade costs is negative and increases with the FOB price (and with quality), and (2) the elasticity of $\epsilon^{f o b}$ with respect to ad valorem trade costs is positive and falls with the FOB price (and with quality). We now discuss whether these mechanisms hold for preferences other than CES.

Irarrazabal et al. (2015) investigate whether the first mechanism holds for different types of preferences: (a) CES utility, (b) quadratic, non-separable utility (Ottaviano, Tabuchi, and Thisse, 2002), (c) translog preferences (Feenstra, 2003), and (d) additively quasi-separable utility (Behrens and Murata, 2007). They show that the elasticity of $\epsilon^{f o b}$ with respect to per unit trade costs is negative with CES. Depending on some parameter values, it is also negative with translog and additively quasi-separable

\footnotetext{
${ }^{14}$ The elasticity of $\epsilon^{f o b}$ with respect to per unit trade costs is negative and increases with the FOB price as $\left(\partial \epsilon^{f o b} / \partial T\right)\left(T / \epsilon^{f o b}\right)=-\sigma\left(1-T / p^{c i f}\right)<0$ and $\left(\partial / \partial p^{f o b}\right)\left(\left(\partial \epsilon^{f o b} / \partial T\right)\left(T / \epsilon^{f o b}\right)\right)=T \tau /\left(\tau p^{f o b}+T\right)^{2}>0$. The elasticity of $\epsilon^{f o b}$ with respect to ad valorem trade costs is positive and decreases with the FOB price as $\left(\partial \epsilon^{f o b} / \partial \tau\right)\left(\tau / \epsilon^{f o b}\right)=$ $T /\left(\tau p^{f o b}+T\right)>0$ and $\left(\partial / \partial p^{f o b}\right)\left(\left(\partial \epsilon^{f o b} / \partial \tau\right)\left(\tau / \epsilon^{f o b}\right)\right)=-T \tau /\left(\tau p^{f o b}+T\right)^{2}<0$. See Appendix B.
} 
utility. Instead, it is positive with quadratic preferences. They also demonstrate that for all demand systems, this elasticity increases with the FOB price.

We examine in Appendix B whether the second mechanism holds for each demand system. We show that the elasticity of $\epsilon^{f o b}$ with respect to ad valorem trade costs is positive in all cases. It decreases with the FOB price when preferences are CES or translog, and with additively quasi-separable utility but for some parameter values only. Instead, it increases with the FOB price when preferences are quadratic. We therefore conclude that the predictions of our model are not specific to CES and can be derived from alternative utility functions with the exception of quadratic preferences.

In Appendix $\mathrm{C}$ we estimate the elasticities of $\epsilon^{f o b}$ with respect to per unit and ad valorem trade costs and we examine how they vary with quality (as opposed to the FOB price). We show that the elasticity of $\epsilon^{f o b}$ with respect to per unit trade costs (distance) is negative and rises with quality, while the elasticity of $\epsilon^{f o b}$ with respect to ad valorem trade costs (tariffs) is positive and falls with quality.

\section{Data and Descriptive Statistics}

Our data set combines information from different sources: firm-level customs data, wine experts quality ratings, and macroeconomic indicators.

\subsection{Customs Data}

Firm-level exports are collected by the Argentinean customs and were purchased from a private vendor called Nosis (Chen and Juvenal, 2016, 2018). For each transaction we observe the name of the exporting firm, the destination country, the shipment date, the 12-digit HS code, the FOB value (in US dollars) and the volume (in liters) of each wine exported between 2002 and 2009. ${ }^{15}$ The main advantage of our data set is its level of disaggregation as for each wine exported we observe its name, type (red, white, or rosé), grape (Malbec, Chardonnay, etc.), and vintage year. The data set also reports the type of packaging used for shipping. Wines are predominantly exported in boxes or bottles, but they are also shipped in wooden barrels, glass, tin, or tetra pak containers. As prices and markups may vary with the packaging type, we define a wine "product" according to its name, grape, type, vintage year, and container type (while we define a "wine" based on its name, grape, type, and vintage year only). Our sample thus includes 11,158 products corresponding to 8,361 different wines. If we aggregated our data at the 12-digit HS level, we would instead only observe ten different product categories.

By dividing the value by the volume exported at the firm-product-destination-time level, we compute FOB unit values as a proxy for export prices. As we do not observe the currency of invoicing, we measure unit values in US dollars per liter. The Datamyne, a private vendor of international trade

\footnotetext{
${ }^{15}$ Due to confidentiality reasons, the customs office does not report the exporter's name. Nosis therefore uses its own market knowledge to identify a first, a second, and a third probable exporter. To identify the exporter's identity we collected from the Instituto Nacional de Vitivinicultura the name of the producer and of the wholesaler authorized to export each wine, and we compared them against the probable exporters reported by Nosis.
} 
data, indeed reports that 88 percent of Argentinean wine exports (HS 2204) between 2005 and 2008 were priced in US dollars. Given that unit values are defined for positive exports only, our analysis focuses on the intensive margin of adjustment (we deal with the extensive margin in Appendix D).

We argue that our unit values can plausibly be interpreted as prices. On the one hand, unit values are defined at the individual product level. This means we can compare the unit values of a given product exported by a given firm at a given point in time across destinations, holding quality constant. This is clearly an advantage over other commonly used trade data sets where unit values are defined at the $\mathrm{CN}$ or HS levels, and therefore measure for each product category the average price of different varieties with potentially heterogeneous levels of quality (Bastos and Silva, 2010; Görg et al., 2017; Harrigan et al., 2015; Manova and Zhang, 2012; Martin, 2012). On the other hand, as the volume is only reported in liters, the unit of measurement of our unit values is homogeneous across products.

We clean up the raw data in several ways. We only keep the FOB transactions and we exclude the wines produced outside of Argentina. We only include wine producers in the sample such that each wine is exported by a single firm (wholesalers and retailers are excluded, but as we show in Section 6 our results remain robust to including intermediaries in the sample). We drop the shipments containing less than 4.5 liters (the latter corresponds to six $75 \mathrm{cl}$ bottles) to discard commercial samples exported for marketing and promotion. We omit a few observations where the vintage year reported is ahead of the shipment year, and the cases where the value of exports is positive, but the volume is reported as zero. We aggregate the data at quarterly frequency between 2002Q1 and 2009Q4. As we show in Section 6, our results remain robust to aggregating the data at annual frequency. Finally, to eliminate potential outliers, we calculate the median unit value charged by each exporter in each time period, and we drop the observations for which the unit value exceeds 100 times the median, or falls below the median divided by 100 .

\subsection{Quality}

We measure quality using the time-invariant quality ratings published by the Wine Spectator and Robert Parker (Chen and Juvenal, 2016, 2018). The wines are assessed in blind tastings, and the ratings are given on a $(50,100)$ scale according to the wine's name, grape, type, and vintage year. A larger score indicates a higher quality. Table 1 describes the two rating classifications.

Table 1: Quality Ratings

\begin{tabular}{ll|ll}
\hline Wine Spectator (50,100) & & Robert Parker (50,100) & \\
\hline \hline Great & $95-100$ & Extraordinary & $96-100$ \\
Outstanding & $90-94$ & Outstanding & $90-95$ \\
Very good & $85-89$ & Above average/very good & $80-89$ \\
Good & $80-84$ & Average & $70-79$ \\
Mediocre & $75-79$ & Below average & $60-69$ \\
Not recommended & $50-74$ & Unacceptable & $50-59$ \\
\hline
\end{tabular}

Notes: Both the Wine Spectator and Parker rating systems classify the quality scores into six different bins. 
When we match the wines from the customs data set with the quality ratings of the Wine Spectator by name, type, grape, and vintage year, we end up with 237 producers exporting 8,361 wines (11,158 products) with 1,066 different names, three types, 24 grapes, and 22 vintage years (from 1977 to 2009). The lowest rated wine receives a score of 55, and the highest a score of 97 . When matching with the Parker ratings, we only observe 2,960 wines (4,128 products) exported by 151 firms (with 443 different names, three types, 21 grapes, and 20 vintage years), and the scores vary between 72 and 98 (i.e., we only observe four of the six bins listed in Table 1). The mean absolute difference between the Wine Spectator and Parker ratings is equal to 1.96, with a standard deviation of 3.19. Still, the two ratings are positively correlated as Pearson's correlation is equal to 0.53, while Kendall's correlation index of concordance is 0.36 . We rely on the Wine Spectator for our main regressions because it has the largest coverage of Argentinean wines. The Parker ratings are used as a robustness check only.

\subsection{Macroeconomic Data}

Bilateral distances (in kilometers) are from the Centre d'Etudes Prospectives et d'Informations Internationales (CEPII). We use the population-weighted great circle distance between the largest cities of two countries. Bilateral ad valorem tariffs for wine (HS 2204), at annual frequency, are obtained from the United Nations Conference on Trade and Development TRAINS database. We use the effectively applied weighted average tariff rates expressed in percentage terms (our results are similar if we use the effectively applied simple average tariff rates). Annual PPP GDPs and GDPs per capita (in constant 2011 US dollars) are from the World Bank's World Development Indicators (measuring real GDP and GDP per capita without any adjustment for PPP yields very similar results). Quarterly nominal exchange rates are from the International Financial Statistics of the International Monetary Fund. Each country's total wine production and wine production and consumption per capita (in liters and at annual frequency) are from Anderson and Nelgen (2011).

\subsection{A First Glance at the Data}

Our sample includes 237 exporters, 8,361 wines (11,158 products), and 95 destination countries between 2002Q1 and 2009Q4 (91,810 observations). It represents 69 percent of the total value of red, white, and rosé wine exported over the period.

Table 2 summarizes our trade data by year, and shows that the number of exporters, wines, and products increased threefold between 2002 and 2009. A total of 926 wines were exported by 70 different firms in 2002, while 191 firms exported 2,677 different wines in 2009. The number of export markets rose from 62 in 2002 to 77 in 2009. The mean number of exported wines and of destinations per firm, and the mean number of destinations per wine also increased over time (the number of observations, firms, destinations, and the mean number of destinations per firm and per wine fell in 2009 due to the global financial crisis, see Chen and Juvenal, 2018).

Table 3 reports descriptive statistics by quality bin of the Wine Spectator. "Good" and "Very good" wines represent the largest share of the sample (in terms of number of observations, firms, wines, 
Table 2: Summary Statistics

\begin{tabular}{lcccccccc}
\hline Year & Observations & Firms & Products & Wines & Destinations & $\begin{array}{c}\text { Wines } \\
\text { per firm }\end{array}$ & $\begin{array}{c}\text { Destinations } \\
\text { per firm }\end{array}$ & $\begin{array}{c}\text { Destinations } \\
\text { per wine }\end{array}$ \\
\hline \hline 2002 & 3,548 & 70 & 1,159 & 926 & 62 & 33.3 & 16.2 & 6.4 \\
2003 & 6,087 & 94 & 1,536 & 1,201 & 61 & 35.1 & 18.1 & 8.2 \\
2004 & 8,104 & 123 & 1,827 & 1,443 & 66 & 33.1 & 18.9 & 9.4 \\
2005 & 11,072 & 143 & 2,270 & 1,784 & 67 & 35.6 & 20.9 & 11.1 \\
2006 & 14,026 & 166 & 2,713 & 2,132 & 77 & 39.0 & 20.7 & 11.5 \\
2007 & 16,018 & 178 & 2,961 & 2,391 & 78 & 40.1 & 22.5 & 12.8 \\
2008 & 17,130 & 196 & 2,996 & 2,508 & 80 & 43.0 & 21.8 & 12.8 \\
2009 & 15,825 & 191 & 3,208 & 2,677 & 77 & 45.7 & 20.4 & 10.8 \\
\hline
\end{tabular}

Notes: For each year in the sample, the table reports the number of observations, exporters, products, wines, and destinations, and the mean number of wines per exporter, destinations per exporter, and destinations per wine.

products, destinations, and export share in the sample). Instead, "Great" and "Not recommended" wines have the smallest coverages. "Great" wines are exported to fewer countries which are, on average, richer. Consistent with quality sorting and the Alchian and Allen (1964) conjecture, "Great" wines are also exported to more distant locations. Higher quality wines are on average more expensive, but the correlation between unit values and quality in our sample is only 36 percent.

Table 3: Descriptive Statistics by Quality Bin

\begin{tabular}{llllllllll}
\hline & Obs. & Firms & Products & Wines & $\begin{array}{c}\text { Export } \\
\text { shares }\end{array}$ & $\begin{array}{c}\text { Unit } \\
\text { values }\end{array}$ & $\begin{array}{c}\text { Dest. } \\
\text { Distance }\end{array}$ & $\begin{array}{c}\text { GDP per } \\
\text { capita }\end{array}$ \\
\hline \hline Great & 201 & 7 & 53 & 44 & $0.11 \%$ & 27.98 & 30 & 9,511 & 33,782 \\
Outstanding & 12,944 & 79 & 1,686 & 1,282 & $16.61 \%$ & 12.42 & 81 & 8,873 & 31,192 \\
Very good & 36,379 & 147 & 3,416 & 2,488 & $44.00 \%$ & 4.71 & 91 & 8,970 & 30,162 \\
Good & 36,638 & 181 & 4,823 & 3,577 & $34.11 \%$ & 4.28 & 90 & 8,977 & 30,866 \\
Mediocre & 5,218 & 97 & 1,100 & 909 & $4.39 \%$ & 3.91 & 80 & 8,897 & 33,012 \\
Not recommended & 430 & 26 & 80 & 61 & $0.78 \%$ & 3.89 & 52 & 8,391 & 29,252 \\
\hline
\end{tabular}

Notes: For each quality bin of the Wine Spectator, the table reports the number of observations, exporters, products, wines, the export share (in \%), the mean unit value (in US dollars per liter), the number of destinations, the mean distance (in kilometers), and the mean income per capita of the destination countries (in PPP constant 2011 US dollars).

Table 4 describes our data by continent, and shows that North America is the main destination for wine exports (in terms of number of exporters, wines, and share of exports). Compared to Europe or Asia which have a similar income per capita, North America is indeed larger, sets lower tariffs, and is closer to Argentina. South America is the closest region and sets the lowest tariffs, but it only imports 13 percent of wine exports as it also has a low GDP and GDP per capita. The export share to Africa is negligible, but it is the smallest and poorest region and sets high tariffs. Besides, tariffs tend to rise with distance (their correlation in our sample is 42 percent). Unit values tend to fall with tariffs (their correlation is -9.4 percent), but they do not vary strongly with the distance to each region. Continents are, however, an imperfect proxy for distance (Argentina is for instance closer to North America than to Africa, but the distance to Canada is 9,391 kilometers against 7,702 kilometers to Ghana). 
Table 4: Descriptive Statistics by Continent

\begin{tabular}{lllllllllll}
\hline & Obs. & Firms & Wines & $\begin{array}{c}\text { Export } \\
\text { shares }\end{array}$ & $\begin{array}{c}\text { Unit } \\
\text { values }\end{array}$ & Dest. & Distance & $\begin{array}{c}\text { GDP per } \\
\text { capita }\end{array}$ & GDP & Tariffs \\
\hline \hline S. America & 20,821 & 165 & 4,299 & $12.93 \%$ & 5.98 & 11 & 2,612 & 10,895 & 1,020 & $3.86 \%$ \\
N. America & 28,862 & 225 & 5,779 & $48.69 \%$ & 5.71 & 20 & 7,983 & 35,913 & 7,770 & $5.53 \%$ \\
Africa & 372 & 32 & 234 & $0.09 \%$ & 3.91 & 8 & 8,493 & 6,546 & 131 & $25.81 \%$ \\
Europe & 32,672 & 189 & 5,386 & $33.67 \%$ & 5.29 & 36 & 11,602 & 38,590 & 1,240 & $28.67 \%$ \\
Asia & 9,083 & 127 & 2,364 & $4.62 \%$ & 5.84 & 20 & 17,066 & 32,689 & 2,500 & $19.68 \%$ \\
\hline
\end{tabular}

Notes: For each continent, the table reports the number of observations, exporters, wines, the export share (in \%), the mean unit value (in US dollars per liter), the number of destinations, and the mean distance (in kilometers), GDP per capita (in PPP constant 2011 US dollars), GDP (in billion PPP constant 2011 US dollars), and tariff (in \%).

Lastly, we regress (log) unit values on product-time and destination country dummy variables. As the product-time fixed effects identify the variation in markups, the country fixed effects capture the mean markup in each destination. Figure 1 plots the country fixed effects against (log) distance. The slope is equal to 0.027 (significant at the one percent level). If distance doubles, markups increase by 1.9 percent on average $\left(2^{0.027}-1\right)$. Markups are highest for Luxembourg (LUX) which is distant from Argentina (and has a high GDP per capita), and low for Uruguay (URY) which is close to Argentina (and has a low GDP per capita). They are, however, also low for Saint Lucia (LCA) and Belarus (BLR) which are both relatively distant from Argentina (but they also have a low GDP per capita). ${ }^{16}$

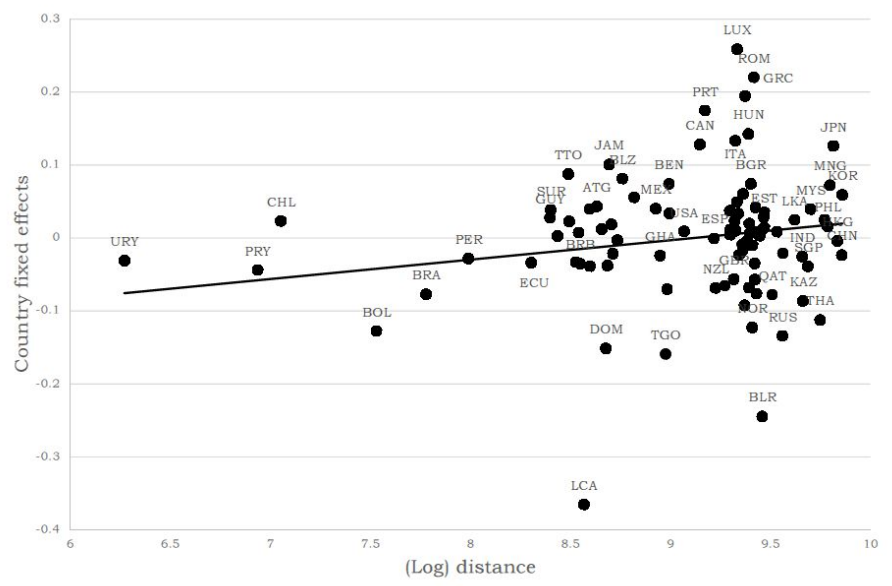

Figure 1: Destination-specific mean markups against (log) distance.

\section{Empirical Analysis}

To test the predictions of our model, and establish how exporters adjust their prices and markups across destinations depending on distance, tariffs, and the quality of their exports, we estimate the

\footnotetext{
${ }^{16}$ Visual inspection of the data also provides evidence of price discrimination. If we focus on the wine product shipped to the largest number of countries in a given quarter (35 countries in 2009Q2), its unit value in that quarter varies between 1.78 and 4.68 US dollars per liter for exports to Honduras (6,085 kilometers) and Belgium (11,305 kilometers). As the marginal cost is the same across markets, the higher price for the more distant country indicates a higher markup.
} 
following reduced-form regression:

$$
\begin{aligned}
\ln u v_{i j k, t}= & \alpha_{1} \ln d i s t_{j}+\alpha_{2} \ln \text { dist }_{j} \times \text { quality }_{k}+\alpha_{3} \ln t a r_{j, t}+\alpha_{4} \ln \text { tar }_{j, t} \times \text { quality }_{k} \\
& +\alpha_{5} z_{j, t}+D_{k, t}+\varepsilon_{i j k, t},
\end{aligned}
$$

where $u v_{i j k, t}$ is the FOB unit value of wine product $k$ exported by firm $i$ to country $j$ in quarter $t$ (in US dollars per liter). The quality of wine $k$, denoted by quality $y_{k}$, is measured using the Wine Spectator ratings. The distance dist ${ }_{j}$ between Argentina and country $j$, and the (annual) tariff tar $_{j, t}$ imposed by country $j$ on wine imports from Argentina in quarter $t$ are both interacted with quality (we use the logarithm of one plus the tariff rate). As our model predicts that prices and markups rise with distance and fall with tariffs, especially for lower quality exports, we expect $\alpha_{1}+\left(\alpha_{2} \times\right.$ qualityk $)>0$ with $\alpha_{2}<0$ (Prediction 1), and $\alpha_{3}+\left(\alpha_{4} \times\right.$ quality $\left._{k}\right)<0$ with $\alpha_{4}>0$ (Prediction 2).

We also control for destination-specific characteristics $z_{j, t}$ including (log) GDP, GDP per capita, and remoteness, measured at annual frequency. ${ }^{17}$ We expect GDP per capita to be associated with higher prices, reflecting that wealthier countries have a stronger preference for quality (Bastos and Silva, 2010; Görg et al., 2017; Hummels and Skiba, 2004; Lugovskyy and Skiba, 2015; Manova and Zhang, 2012; Martin, 2012). As unit values depend on average prices in each export market, they should also be higher in remote locations which are less competitive and have higher prices (Martin, 2012). They should instead be lower in larger countries where there is tougher competition (Baldwin and Harrigan, 2011; Görg et al., 2017; Harrigan et al., 2015; Martin, 2012). ${ }^{18}$

We perform within estimations and include product-time fixed effects $D_{k, t}$ (which are also firm specific). The direct effect of quality therefore drops out from the regression. As the product-time fixed effects enable us to isolate the variation in unit values across destinations for a given exporter and a given product at each point in time, they control for selection and composition effects across products within firms. And since product-specific marginal costs do not vary across destinations, the variation in unit values across markets identifies the variation in markups. ${ }^{19}$ Robust standard errors are adjusted for clustering at the destination-time level (our results remain robust to multi-level clustering by destination and firm).

We then estimate a more stringent specification:

$$
\ln u v_{i j k, t}=\phi_{1} \ln \text { dist }_{j} \times q u a l i t y_{k}+\phi_{2} \ln \operatorname{tar}_{j, t} \times q_{u a l i t y}+D_{k, t}+D_{i j, t}+v_{i j k, t},
$$

where the firm-destination-time fixed effects $D_{i j, t}$ control for factors such as the time-varying demand or taste of a country for a firm's exports, or the existence of contracts negotiated by some exporters

\footnotetext{
${ }^{17} \mathrm{~A}$ country is remote if it is geographically isolated from other countries or is close to small countries but far away from large economies. Remoteness is calculated as $\sum_{j}\left(G D P_{j} / \text { dist }_{j}\right)^{-1}$ (Baldwin and Harrigan, 2011).

${ }^{18}$ Our results remain robust to including a dummy variable for the members of Mercosur (Brazil, Paraguay, Uruguay, and Venezuela) and its associate members (Bolivia, Chile, Colombia, Ecuador, Guyana, Peru, and Suriname).

${ }^{19}$ Selection and composition imply that prices vary across markets because different wines are sold in different countries. Price discrimination instead captures that prices vary across markets conditional on positive exports. By absorbing in each quarter the wines shipped to a single country, the product-time fixed effects thus control for selection and composition.
} 
in some destinations. They also absorb all destination-specific factors including distance, tariffs, GDP, GDP per capita, and remoteness.

Our empirical analysis proceeds in three steps. In Section 4.1 we first revisit evidence from the prior literature that firm-level export prices rise with distance and fall with tariffs. We then turn to our first contribution and we show that variable markups matter in explaining the effects of distance and tariffs on the variation in prices across markets. Our second contribution in Section 4.2 is to demonstrate that the effects of distance and tariffs on markups are smaller in magnitude for higher quality exports.

\subsection{Homogeneous Trade Cost Effects}

To identify the homogeneous effects of bilateral distance and tariffs, we estimate equation (14) but we omit the two interaction terms with quality. Also, we replace the product-time fixed effects with firm-time dummy variables, and we control for product characteristics by including grape, type, vintage year, HS-level, packaging, and province of origin of the grapes fixed effects. Fixed effects for the wine names are not included as they are collinear with the firm fixed effects (as each wine is exported by one producer only). The firm-time fixed effects control for time-varying characteristics of the exporters such as productivity, firm size, or credit constraints. They also imply that we identify the variation in unit values across products and destinations for a given exporter at a given point in time. The effects of distance and tariffs on unit values can therefore be driven by selection across products within firms, Alchian and Allen (1964) effects, and/or variable markups.

The results are reported in column (1) of Table 5. Unit values increase with distance and fall with tariffs (Görg et al., 2017; Hummels and Skiba, 2004; Lugovskyy and Skiba, 2016). Prices are higher in richer and remote destinations, and lower in larger markets. Column (2) further controls for quality. Higher quality wines are shipped at a higher price, as in equation (7). And for a given quality, prices are higher in more distant countries, and lower in markets with higher tariffs.

Column (3) includes product-time fixed effects and quality drops out from the regression (the coefficient on remoteness also turns insignificant). Notably, the distance coefficient remains positive and the tariff coefficient negative. This specification thus provides direct evidence that exporters set higher markups in more distant locations, and lower markups in countries with higher tariffs.

Compared to a value of 0.039 in column (2), the distance coefficient falls to 0.021 in column (3). If distance doubles, prices and markups increase by 2.74 and 1.47 percent on average. Variable markups thus contribute to around half of the impact of distance on the variation in within firm prices across markets, the other half being due to selection or composition effects across products within firms. Likewise, the magnitude of the tariff coefficient falls from -0.113 to -0.086 . If tariffs double (from their mean which is equal to 14.87 percent), prices and markups fall by 1.37 and 1.04 percent on average. Markups thus explain three-quarters of the effect of tariffs on the variation in firm-level prices across markets, the rest being due to selection or composition effects across products within firms. ${ }^{20}$

\footnotetext{
${ }^{20}$ Our model predicts that the elasticities with respect to distance and tariffs are smaller in magnitude for prices
} 
Table 5: Homogeneous Trade Cost Effects

\begin{tabular}{|c|c|c|c|c|}
\hline & $(1)$ & $(2)$ & $(3)$ & $(4)$ \\
\hline ln distance & $\begin{array}{l}0.042^{* * *} \\
(0.008)\end{array}$ & $\begin{array}{l}0.039^{* * *} \\
(0.008)\end{array}$ & $\begin{array}{l}0.021^{* * *} \\
(0.005)\end{array}$ & - \\
\hline $2,900<$ distance $<7,700$ & - & - & - & $\begin{array}{l}0.016^{*} \\
(0.008)\end{array}$ \\
\hline $7,700<$ distance $<14,200$ & - & - & - & $\begin{array}{l}0.043^{* * *} \\
(0.012)\end{array}$ \\
\hline distance $>14,200$ & - & - & - & $\begin{array}{l}0.061^{* * *} \\
(0.012)\end{array}$ \\
\hline quality & - & $\begin{array}{l}0.032^{* * *} \\
(0.001)\end{array}$ & - & - \\
\hline ln tariffs & $\begin{array}{l}-0.115^{* * *} \\
(0.040)\end{array}$ & $\begin{array}{l}-0.113^{* * *} \\
(0.040)\end{array}$ & $\begin{array}{l}-0.086^{* * *} \\
(0.022)\end{array}$ & $\begin{array}{l}-0.079^{* * *} \\
(0.022)\end{array}$ \\
\hline ln remoteness & $\begin{array}{l}0.048^{* * *} \\
(0.013)\end{array}$ & $\begin{array}{l}0.047^{* * *} \\
(0.013)\end{array}$ & $\begin{array}{l}0.011 \\
(0.008)\end{array}$ & $\begin{array}{l}0.013 \\
(0.008)\end{array}$ \\
\hline $\ln$ GDP & $\begin{array}{l}-0.024^{* * *} \\
(0.002)\end{array}$ & $\begin{array}{l}-0.024^{* * *} \\
(0.002)\end{array}$ & $\begin{array}{l}-0.013^{* * *} \\
(0.002)\end{array}$ & $\begin{array}{l}-0.014^{* * *} \\
(0.002)\end{array}$ \\
\hline $\ln \mathrm{GDP} / \mathrm{cap}$ & $\begin{array}{l}0.020^{* * *} \\
(0.007)\end{array}$ & $\begin{array}{l}0.021^{* * *} \\
(0.007)\end{array}$ & $\begin{array}{l}0.011^{* *} \\
(0.005)\end{array}$ & $\begin{array}{l}0.007 \\
(0.005) \\
\end{array}$ \\
\hline R-squared & 0.584 & 0.596 & 0.838 & 0.838 \\
\hline Observations & 91,307 & 91,307 & 71,952 & 71,952 \\
\hline Firm-time fixed effects & Yes & Yes & No & No \\
\hline Product characteristics fixed effects & Yes & Yes & No & No \\
\hline Product-time fixed effects & No & No & Yes & Yes \\
\hline
\end{tabular}

Notes: The dependent variable is the log FOB unit value of exports (in US dollars per liter). Robust standard errors adjusted for clustering by destination-time between parentheses. ${ }^{* * *},{ }^{* *}$, and ${ }^{*}$ indicate significance at the one, five, and ten percent levels.

Column (4) reports non-parametric estimates and regresses unit values on distance interval dummy variables (the dummy for the first interval below 2,900 kilometers is omitted). ${ }^{21}$ Again, markups rise with distance. Exporting to non-neighboring Latin American countries (between 2,900 and 7,700 kilometers) increases markups by $1.6 \mathrm{log}$ points, on average. The effect is equal to $4.3 \mathrm{log}$ points for the countries located between 7,700 and 14,200 kilometers away from Argentina, and to 6.1 log points for the most distant destinations (above 14,200 kilometers). Higher tariffs reduce markups.

\subsection{Heterogeneous Trade Cost Effects}

We now explore the heterogeneous effects of bilateral distance and tariffs on the markups of exports differentiated by quality. Column (1) of Table 6 includes an interaction term between distance and quality, while column (2) also interacts tariffs with quality. Consistent with Predictions 1 and 2, the coefficient on the distance interaction is negative, while the coefficient on the tariff interaction is positive. The elasticities of markups with respect to trade costs are therefore smaller in magnitude for higher quality exports. ${ }^{22}$

(equations 9 and 11) than for markups (equations 10 and 12). We therefore compare the results for markups in column (3) with the ones we obtain for prices if we regress the specification in column (2) on the sample of column (3). The tariff elasticity is indeed smaller in magnitude at -0.072 , while the distance elasticity is larger at 0.028 .

${ }^{21}$ The first group (below 2,900 kilometers) includes Argentina's neighboring countries. The second (2,900-7,700 kilometers) contains other Latin American countries. The third (7,700-14,200 kilometers) includes the US, Canada, Australia, New Zealand, Africa, Europe, and the Middle East. The last group (above 14,200 kilometers) contains Asian countries.

${ }^{22}$ Cavallo, Gopinath, Neiman, and Tang (2019) find that higher tariffs reduce export prices to a larger extent for undifferentiated than for differentiated goods. 
Table 6: Heterogeneous Trade Cost Effects

\begin{tabular}{|c|c|c|c|c|}
\hline & $(1)$ & $(2)$ & $(3)$ & $(4)$ \\
\hline ln distance & $\begin{array}{l}0.303^{* * *} \\
(0.056)\end{array}$ & $\begin{array}{l}0.446^{* * *} \\
(0.061)\end{array}$ & - & - \\
\hline ln distance $\times$ quality & $\begin{array}{l}-0.003^{* * *} \\
(0.001)\end{array}$ & $\begin{array}{l}-0.005^{* * *} \\
(0.001)\end{array}$ & $\begin{array}{l}-0.003^{* * *} \\
(0.001)\end{array}$ & ${ }_{(0.001)}^{-0.004^{* * *}}$ \\
\hline ln tariffs & $\begin{array}{l}-0.087^{* * *} \\
(0.022)\end{array}$ & $\begin{array}{c}-1.986^{* * *} \\
(0.362)\end{array}$ & - & - \\
\hline ln tariffs $\times$ quality & - & $\begin{array}{l}0.022^{* * *} \\
(0.004)\end{array}$ & $\begin{array}{l}0.027^{* * *} \\
(0.004)\end{array}$ & $\begin{array}{l}0.022^{* * *} \\
(0.005)\end{array}$ \\
\hline ln remoteness & $\begin{array}{l}0.012 \\
(0.008)\end{array}$ & $\begin{array}{l}0.011 \\
(0.008)\end{array}$ & - & - \\
\hline $\ln$ GDP & $\begin{array}{l}-0.013^{* * *} \\
(0.002)\end{array}$ & $\begin{array}{l}-0.013^{* * *} \\
(0.002)\end{array}$ & - & - \\
\hline $\ln$ GDP/cap & $\begin{array}{l}0.010^{* *} \\
(0.005)\end{array}$ & $\begin{array}{l}0.010^{* *} \\
(0.005)\end{array}$ & - & - \\
\hline R-squared & 0.838 & 0.838 & 0.922 & 0.909 \\
\hline Observations & 71,952 & 71,952 & 66,941 & 69,219 \\
\hline Packaging & Yes & Yes & Yes & No \\
\hline Product-time fixed effects & Yes & Yes & Yes & Yes \\
\hline Firm-destination-time fixed effects & No & No & Yes & Yes \\
\hline
\end{tabular}

Notes: The dependent variable is the log FOB unit value of exports (in US dollars per liter). Robust standard errors adjusted for clustering by destination-time between parentheses. ${ }^{* * *}$ and ${ }^{* *}$ indicate significance at the one and five percent levels. In (4), a product is defined according to a wine's name, grape, type, and vintage year only.

How large are the heterogeneous effects of trade costs? Based on the estimates of column (2), Panels (a) and (b) of Figure 2 plot the distance and tariff elasticities at each quality level in our sample (between 55 and 97) and their confidence intervals. At the mean value of quality (equal to 85), the distance elasticity is equal to 0.022 . It is equal to 0.052 at the $5^{\text {th }}$ percentile of the quality distribution (equal to 79 ), and falls to -0.007 (which is insignificant) at the $95^{\text {th }}$ percentile (equal to 91). Likewise, the tariff elasticity is equal to -0.094 at the mean value of quality. Its magnitude falls from -0.227 at the $5^{\text {th }}$ percentile of the quality distribution to 0.039 (which is not significant) at the $95^{\text {th }}$ percentile. For quality levels above 91, the distance elasticity becomes negative and the tariff elasticity positive. The dampening effect of quality thus outweighs the effects of trade costs such that firms lower their markups in more distant markets, and raise them in high-tariff countries.

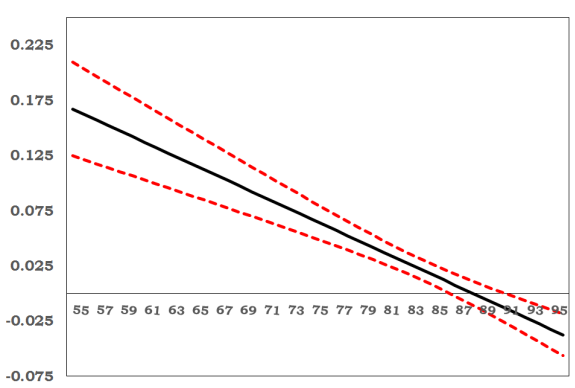

(a) Distance

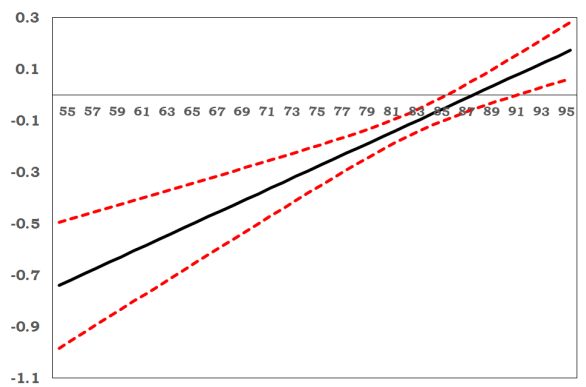

(b) Tariffs

Figure 2: Bilateral distance and tariff elasticities by quality level (based on the estimates reported in column 2 of Table 6). 95 percent confidence intervals reported as dashed lines. 
Column (3) reports the results of estimating equation (15). The coefficient on distance interacted with quality remains negative, while the one on the interaction between tariffs and quality is positive. Finally, column (4) shows that our results remain robust if we define a product according to a wine's name, grape, type, and vintage year only (and ignore its packaging type).

As we only observe unit values when a firm exports to a given country, our regressions do not control for the possibility that firms may decide to export to some markets but not to others. By implementing the three-step estimator of Harrigan et al. (2015), we show in Appendix D that our results remain robust to removing selection bias across firms. We explain export values using a two-step Heckman estimator and we include the residuals as a selection control in the unit values regression.

\subsection{Alternative Mechanisms}

We consider alternative explanations to our mechanism which may explain the direct and heterogeneous effects of trade costs on markups.

\subsubsection{Intensity of Competition}

In our model, the substitution elasticity $\sigma$ determines the elasticity of demand to the CIF price, and it therefore captures the degree of competition in foreign markets. It also affects the price and markup (equations 7 and 8). The model assumes that $\sigma$ is constant, but this may not be true in the data as $\sigma$ could potentially vary across markets and quality levels. And for the goods with a lower $\sigma$ facing a lower degree of competition, firms can be expected to adjust their markups less in response to changes in trade costs. Our estimates could hence be biased if a higher quality is associated with a lower $\sigma$.

To address this issue we estimate substitution elasticities across countries and quality levels. We follow Imbs and Méjean (2015) who adapt Feenstra's (1994) approach to estimate disaggregated substitution elasticities using trade data. Feenstra (1994) estimates a demand schedule for US industries using country-industry fixed effects as instruments. Identification depends on the cross-section of exporters and is achieved in deviation from a reference country. When this approach yields estimates that do not match the theoretically plausible values for $\sigma$, Imbs and Méjean (2015) apply the grid search algorithm of Broda and Weinstein (2006) that minimizes the sum of squared residuals over the intervals of plausible values for $\sigma$, in which case the standard errors are boostrapped with 1,000 replications.

As we only observe one country exporting to many markets, to achieve identification we define each

exporting entity as a firm. Besides, due to the small number of observations for "Great" and "Not recommended" wines, we group our data into three quality categories: Low quality (which includes the "Not recommended" and "Mediocre" wines), Medium quality ("Good" and "Very good" wines), and High quality ("Great" and "Outstanding" wines). All wines within each category are therefore assumed to be equally substitutable. Lastly, as the estimation requires us to observe lagged export values and unit values, to maximize data coverage we aggregate our data at annual frequency. Due to limited data coverage in 2002 and 2003 we restrict our estimation to the 2004-2009 period only. 
We provide two sets of estimates. First, we estimate one substitution elasticity for each of the three quality categories, constraining them to be identical across importing countries. We find that $\sigma$ is equal to 17.71 for Low quality, 11.82 for Medium quality, and to 8.37 for High quality. Higher quality wines have a lower elasticity of substitution, and therefore face less competition in export markets. Second, we let the three elasticities vary across destinations. This yields 75 different elasticities ranging from 1.41 to 41.73 with an average of 9.92 and a standard deviation of 9.27 (due to data limitations, we are unable to estimate $\sigma$ for all countries and quality categories in our sample). A simple regression (with firm-time and product characteristics fixed effects) shows that $\sigma$ falls with quality and tariffs while it increases with distance (all coefficients are significant at the one percent level).

Table 7: Alternative Mechanisms: Intensity of Competition

\begin{tabular}{|c|c|c|c|}
\hline & $(1)$ & $(2)$ & $(3)$ \\
\hline ln distance & $\begin{array}{l}0.415^{* * *} \\
(0.083)\end{array}$ & - & - \\
\hline ln distance $\times$ quality & $\begin{array}{l}-0.005^{* * *} \\
(0.001)\end{array}$ & ${ }_{(0.001)}^{-0.004^{* * *}}$ & $\begin{array}{c}-0.002^{*} \\
(0.001)\end{array}$ \\
\hline $\ln$ distance $\times \ln \sigma$ & $\begin{array}{l}0.027^{* * *} \\
(0.006)\end{array}$ & $\begin{array}{c}-0.002 \\
(0.009)\end{array}$ & $\begin{array}{l}0.076^{* * *} \\
(0.024)\end{array}$ \\
\hline ln tariffs & $\begin{array}{l}-1.673^{* * *} \\
(0.523)\end{array}$ & - & - \\
\hline ln tariffs $\times$ quality & $\begin{array}{l}0.023^{* * *} \\
(0.006)\end{array}$ & $\begin{array}{l}0.025^{* * *} \\
(0.006)\end{array}$ & $\begin{array}{l}0.010^{* *} \\
(0.005)\end{array}$ \\
\hline $\ln$ tariffs $\times \ln \sigma$ & $\begin{array}{l}-0.197^{* * *} \\
(0.039)\end{array}$ & $\begin{array}{l}-0.404^{* * *} \\
(0.060)\end{array}$ & $\begin{array}{c}-0.660^{* * *} \\
(0.124)\end{array}$ \\
\hline ln remoteness & $\begin{array}{c}-0.001 \\
(0.014)\end{array}$ & - & - \\
\hline $\ln \mathrm{GDP}$ & $\begin{array}{l}-0.024^{* * *} \\
(0.003)\end{array}$ & - & - \\
\hline $\ln \mathrm{GDP} / \mathrm{cap}$ & $\begin{array}{l}0.020^{* *} \\
(0.009)\end{array}$ & - & - \\
\hline $\ln \sigma$ & $\begin{array}{l}-0.200^{* * *} \\
(0.049)\end{array}$ & $\begin{array}{c}0.102 \\
(0.075) \\
\end{array}$ & - \\
\hline R-squared & 0.845 & 0.928 & 0.922 \\
\hline Observations & 49,129 & 44,806 & 66,941 \\
\hline Substitution elasticity varies by & Country-quality & Country-quality & Quality \\
\hline Product-time fixed effects & Yes & Yes & Yes \\
\hline Firm-destination-time fixed effects & No & Yes & Yes \\
\hline
\end{tabular}

Notes: The dependent variable is the log FOB unit value of exports (in US dollars per liter). Robust standard errors adjusted for clustering by destination-time between parentheses. ${ }^{* *},{ }^{* *}$, and ${ }^{*}$ indicate significance at the one, five, and ten percent levels. The elasticity of substitution $\sigma$ is estimated using the Imbs and Méjean (2015) methodology.

In column (1) of Table 7 we estimate equation (14) but we further interact distance and tariffs with the (log) elasticity of substitution that varies across destinations and quality categories. The coefficient on the interaction between distance and $\sigma$ is positive, while the one on the interaction between tariffs and $\sigma$ is negative. When trade costs increase, firms adjust their markups less for the wines with a lower $\sigma$, which also tend to have a higher quality. Most importantly, controlling for $\sigma$ does not affect our main conclusions: firms raise their markups in more distant markets, lower them in high-tariff destinations, and these effects are stronger for the wines of lower quality. ${ }^{23}$

\footnotetext{
${ }^{23}$ If we include distance, tariffs, quality, the substitution elasticity and the country controls as regressors (with firm-time and product characteristics fixed effects), a variance decomposition shows that 2.71 percent of the variation in unit values is explained by quality, 0.53 percent by the elasticity of substitution, 0.15 percent by distance, and 0.03 percent by tariffs.
} 
In column (2) we further control for firm-destination-time fixed effects. In column (3) we estimate the same specification as in column (2) but we use the substitution elasticities estimated by quality category only. The coefficient on the interaction between distance and $\sigma$ turns insignificant in column (2). But in both cases, the effects of trade costs on markups continue to be heterogeneous across quality levels. We thus conclude that the intensity of competition in foreign markets is not driving our results.

\subsubsection{Country-level Characteristics}

Our estimates could also be biased if distance and tariffs are correlated with other country-level characteristics affecting the pricing decisions of exporters in each quality segment. For instance, Chen and Juvenal (2016) show that the markups of higher quality exports are more sensitive to changes in real exchange rates. To ensure that our results are not driven by the heterogeneous pricing-to-market behavior of exporters, we control for the exchange rate between the US dollar and the destination's currency (an increase indicates an appreciation of the US dollar) interacted with quality. In column (1) of Table 8, the coefficient on this interaction term is positive, but its inclusion does not substantially modify the size and significance of the coefficients on the distance and tariff interaction terms.

Table 8: Alternative Mechanisms: Country-level Characteristics

\begin{tabular}{|c|c|c|c|c|c|}
\hline & (1) & $(2)$ & $(3)$ & (4) & $(5)$ \\
\hline ln distance $\times$ quality & $\begin{array}{l}-0.004^{* * *} \\
(0.001)\end{array}$ & $\begin{array}{l}-0.005^{* * *} \\
(0.001)\end{array}$ & $\begin{array}{l}-0.004^{* * *} \\
(0.001)\end{array}$ & $\begin{array}{l}-0.004^{* * *} \\
(0.001)\end{array}$ & $\begin{array}{l}-0.009^{* * *} \\
(0.001)\end{array}$ \\
\hline ln tariffs $\times$ quality & $\begin{array}{l}0.026^{* * *} \\
(0.004)\end{array}$ & $\begin{array}{l}0.029^{* * *} \\
(0.004)\end{array}$ & $\begin{array}{l}0.030^{* * *} \\
(0.004)\end{array}$ & $\begin{array}{l}0.030^{* * *} \\
(0.005)\end{array}$ & $\begin{array}{l}0.015^{* * *} \\
(0.004)\end{array}$ \\
\hline $\ln \mathrm{ER} \times$ quality & $\begin{array}{l}0.001^{* *} \\
(0.000)\end{array}$ & - & - & - & - \\
\hline ln GDP/cap × quality & - & $\begin{array}{l}0.002^{* * *} \\
(0.001)\end{array}$ & - & - & - \\
\hline ln wine production/cap $\times$ quality & - & - & $\begin{array}{l}0.001 \\
(0.000)\end{array}$ & - & - \\
\hline ln wine consumption/cap $\times$ quality & - & - & - & $\begin{array}{l}0.002^{* * *} \\
(0.000)\end{array}$ & - \\
\hline ln wine import share $\times$ quality & - & - & - & - & $\begin{array}{c}-0.004^{* * *} \\
(0.001)\end{array}$ \\
\hline R-squared & 0.922 & 0.922 & 0.924 & 0.925 & 0.922 \\
\hline Observations & 66,941 & 66,941 & 56,605 & 44,410 & 66,939 \\
\hline Product-time fixed effects & Yes & Yes & Yes & Yes & Yes \\
\hline Firm-destination-time fixed effects & Yes & Yes & Yes & Yes & Yes \\
\hline
\end{tabular}

Notes: The dependent variable is the log FOB unit value of exports (in US dollars per liter). Robust standard errors adjusted for clustering by destination-time between parentheses. ${ }^{* * *}$ and ${ }^{* *}$ indicate significance at the one and five percent levels. An increase in the exchange rate "ER" indicates an appreciation of the US dollar.

In a related study, Chen and Juvenal (2018) show that the markups of higher quality exports are more sensitive to changes in foreign income. In column (2) we therefore include an interaction between foreign real GDP per capita and quality. The coefficient on the interaction term is positive, but distance and tariffs continue to have heterogeneous effects on the markups of exports differentiated by quality.

Finally, markups may depend on each country's wine production or consumption patterns. In columns (3) and (4) we therefore include interactions between quality and each country's wine production per capita (we use the logarithm of one plus wine production per capita to account for the 
countries not producing wine) or wine consumption per capita. As markups could also be affected by the intensity of wine import competition in each country, in column (5) we interact quality with each country's share of wine import quantities (HS 2204) from Argentina at annual frequency (from the BACI data set). In all cases, the effects of trade costs on markups remain heterogeneous across quality levels (our results also remain robust to interacting remoteness or each country's GDP with quality).

\section{Extensions}

This section discusses extensions. First, we investigate whether our results vary with the destination country's income level. Second, we explore whether our findings vary across different types of exporters. Third, we extend our analysis to manufacturing industries other than wine. Finally, we derive and test the predictions of our model for export volumes.

\subsection{Income Heterogeneity across Destinations}

Consumers in richer countries are generally assumed to have a stronger preference for higher quality goods (Chen and Juvenal, 2016, 2018; Crinò and Epifani, 2012; Fajgelbaum, Grossman, and Helpman, 2011; Feenstra and Romalis, 2014; Hallak, 2006; Manova and Zhang, 2012; Simonovska, 2015). To check if per capita income matters for our results, we classify countries as rich or poor based on whether their income per capita is above or below the sample median. We estimate equation (15) and we multiply the distance and tariff interactions with a dummy variable for the richer destinations. ${ }^{24}$

Table 9: Income Heterogeneity across Destinations

\begin{tabular}{llc}
\hline & $(1)$ & $(2)$ \\
\hline \hline ln distance $\times$ quality & $-0.003^{* *}$ & $-0.003^{* * *}$ \\
& $(0.001)$ & $-0.001)$ \\
ln distance $\times$ quality $\times$ rich & $-0.001^{* *}$ & $(0.000)$ \\
ln tariffs $\times$ quality & $(0.000)$ & -0.007 \\
ln tariffs $\times$ quality $\times$ rich & 0.004 & $(0.009)$ \\
& $(0.005)$ & $0.038^{* * *}$ \\
\hline Rich versus poor & $0.036^{* * *}$ & World Bank GNI \\
R-squared & $(0.007)$ & 0.922 \\
Observations & Median GDP/cap & 66,941 \\
Product-time fixed effects & 0.922 & Yes \\
Firm-destination-time fixed effects & 66,941 & Yes \\
\hline
\end{tabular}

Notes: The dependent variable is the log FOB unit value of exports (in US dollars per liter). Robust standard errors adjusted for clustering by destination-time between parentheses. ${ }^{* * *},{ }^{* *}$, and ${ }^{*}$ indicate significance at the one, five, and ten percent levels.

The results are presented in column (1) of Table 9. The coefficient on the interaction of distance with quality is significant for the two groups of countries, but it is larger in magnitude for the richer destinations. Instead, the effect of tariffs is heterogeneous for the richer markets only. Column (2) shows

\footnotetext{
${ }^{24}$ Argentina's higher income export destinations such as the US and the EU also tend to be farther away. In our sample, the correlation between income per capita and bilateral distance is equal to 60 percent.
} 
that our results remain similar if we instead split our sample using the World Bank's classification of high and low income countries (the threshold is a GNI per capita of 4,035 US dollars in 2011). The heterogeneous effects of trade costs on markups are thus stronger for exports to richer destinations.

\subsection{Firm-level Characteristics}

We explore whether our results vary across exporters depending on their average quality, their size, and their export market shares. To identify differential effects, we estimate equation (15) and we multiply the distance and tariff interactions with a dummy variable for the higher quality firms, the larger firms, and the exporters with larger export market shares.

First, to compare higher and lower quality exporters we divide our sample at the median of average firm-level quality. We define a higher quality exporter as one which average quality is above the median. As shown in column (1) of Table 10, the interactions of distance and tariffs with quality are only significant for the higher quality firms. Heterogeneity in the impact of trade costs on markups is therefore driven by the higher quality exporters.

Table 10: Firm-level Characteristics

\begin{tabular}{lccc}
\hline & $(1)$ & $(2)$ & $(3)$ \\
\hline & Firm quality & Firm size & Market shares \\
\cline { 2 - 4 } ln distance $\times$ quality & -0.001 & 0.001 & $-0.003^{* * *}$ \\
ln distance $\times$ quality $\times$ above median & $(0.001)$ & $(0.001)$ & 0.001 \\
& $-0.005^{* * *}$ & $-0.005^{* *}$ & $(0.000)$ \\
ln tariffs $\times$ quality & $(0.001)$ & $(0.001)$ & 0.008 \\
ln tariffs $\times$ quality $\times$ above median & 0.007 & $0.014^{* *}$ & $(0.007)$ \\
& $(0.005)$ & $0.017^{* *}$ & $0.026^{* * *}$ \\
\hline R-squared & $0.033^{* * *}$ & $0.009)$ & 0.922 \\
Observations & 0.922 & 622 & 66,941 \\
Product-time fixed effects & 66,941 & 66,941 & Yes \\
Firm-destination-time fixed effects & Yes & Yes & Yes \\
\hline
\end{tabular}

Notes: The dependent variable is the log FOB unit value of exports (in US dollars per liter). Robust standard errors adjusted for clustering by destination-time between parentheses. ${ }^{* * *}$ and ${ }^{* *}$ indicate significance at the one and five percent levels. The "above median" dummy variable indicates that average firm-level quality, firm size, or firm export market shares are above the sample median.

Second, we ask whether our results vary with firm-level productivity. As more productive firms tend to charge higher markups (Bellone, Musso, Nesta, and Warzynski, 2014; Berman et al., 2012; Melitz and Ottaviano, 2008), we expect those firms to be better able to adjust their markups across countries and quality levels in response to changes in trade costs. Missing any data on firm-level value-added or employment which are required to calculate productivity, we instead rely on a measure of firm size as the latter correlates strongly with productivity. We calculate the total volume (in liters) of exports for each firm in each year, and we divide our sample between large and small firms based on whether their total yearly exports are above or below the sample median. Column (2) shows that the effect of distance is heterogeneous for the large firms only. The effect of tariffs is heterogeneous for the two groups of firms, but to a larger extent for the bigger firms. 
Lastly, we compare firms based on their export market shares. Amiti, Itskhoki, and Konings (2014) and Atkeson and Burstein (2008) argue that exporters have higher markups in the countries where they own a large share of the market, making it easier to adjust their markups. We thus expect the effects of trade costs on markups to be more strongly heterogeneous for the high market share firms. We construct market shares as each firm's total exports as a share of the total value exported by all firms by destination and year. Relative to the median market share, we split the sample between high and low market share firms. Column (3) shows that the effect of distance is equally heterogeneous for the two groups of firms. Instead, tariffs have heterogeneous effects for the high market share firms only.

To sum up, the heterogeneous effects of distance and tariffs on markups are mainly driven by high performance firms: the larger firms, with higher market shares and exporting a higher quality. Larger firms have higher market shares (the correlation is 0.69). The correlations between firm-level quality, on the one hand, and market shares and firm size, on the other hand, are only equal to 0.09 and 0.10 .

\subsection{Manufacturing Industries}

To demonstrate that our results for export prices generalize to industries other than wine, we rely on the universe of Argentinean firm-level exports (from Nosis). We observe the name of the exporter (identified as the first probable exporter reported by Nosis), the destination country, the transaction date, the 12digit HS code, the FOB value (in US dollars) and the mass (in kilograms) of exports between 2002 and 2009. We aggregate the data at quarterly frequency and unit values are in US dollars per kilogram. We focus on manufacturing industries (HS 30-38 and 42-97, Lugovskyy and Skiba, 2016), and we define a product at the 8-digit HS level. This level of disaggregation thus prevents us from identifying the variation in markups. Finally, we drop the observations for which the unit value exceeds 100 times the median unit value per firm-product-time, or falls below the median divided by 100 .

As quality is unobserved, we follow Bernini and Tomasi (2015) who adapt the Khandelwal (2010) procedure to estimate the quality of exports at the firm-product-destination-time level (Chen and Juvenal, 2018). See Appendix E for details. The effectively applied weighted average tariff rates (in percentage terms), obtained from the United Nations Conference on Trade and Development TRAINS database, are reported at the 6-digit HS level and at annual frequency. Our sample includes 9,724 exporters, 3,155 products, and 92 destination countries (462,127 observations). As each product can be exported by more than one firm we now control for firm-product-time fixed effects.

The results in Table 11 provide strong evidence that our findings for export prices hold more generally for manufacturing industries other than wine. Unit values rise with distance, income per capita, and remoteness, and fall with a country's size and tariffs (column 1). Higher quality goods are exported at a higher price (column 2). The magnitude of the effects of distance and tariffs on unit values is smaller for higher quality exports (column 3), and this finding remains robust to controlling for firm-destination-time fixed effects (column 4). 
Table 11: Manufacturing Industries

\begin{tabular}{|c|c|c|c|c|}
\hline & $(1)$ & $(2)$ & $(3)$ & (4) \\
\hline ln distance & $\begin{array}{l}0.035^{* * *} \\
(0.003)\end{array}$ & $\begin{array}{l}0.035^{* * *} \\
(0.003)\end{array}$ & $\begin{array}{l}0.035^{* * *} \\
(0.003)\end{array}$ & - \\
\hline quality & - & $\begin{array}{l}0.037^{* * *} \\
(0.002)\end{array}$ & $\begin{array}{l}0.056^{* * *} \\
(0.008)\end{array}$ & $\begin{array}{l}0.062^{* * *} \\
(0.010)\end{array}$ \\
\hline ln distance $\times$ quality & - & - & $\begin{array}{c}-0.003^{* *} \\
(0.001)\end{array}$ & $\begin{array}{l}-0.005^{* * *} \\
(0.001)\end{array}$ \\
\hline ln tariffs & $\begin{array}{c}-0.101^{* *} \\
(0.046)\end{array}$ & $\begin{array}{c}-0.084^{*} \\
(0.045)\end{array}$ & $\begin{array}{c}-0.079^{*} \\
(0.045)\end{array}$ & $\begin{array}{c}-0.007 \\
(0.093)\end{array}$ \\
\hline ln tariffs $\times$ quality & - & - & $\begin{array}{l}0.102^{* * *} \\
(0.035)\end{array}$ & $\begin{array}{l}0.127^{* * *} \\
(0.039)\end{array}$ \\
\hline ln remoteness & $\begin{array}{l}0.031^{* * *} \\
(0.010)\end{array}$ & $\begin{array}{l}0.040^{* * *} \\
(0.011)\end{array}$ & $\begin{array}{l}0.039^{* * *} \\
(0.011)\end{array}$ & - \\
\hline $\ln$ GDP & $\begin{array}{l}-0.028^{* * *} \\
(0.002)\end{array}$ & $\begin{array}{l}-0.028^{* * *} \\
(0.002)\end{array}$ & $\begin{array}{l}-0.028^{* * *} \\
(0.002)\end{array}$ & - \\
\hline ln GDP/cap & $\begin{array}{l}0.035^{* * *} \\
(0.006)\end{array}$ & $\begin{array}{l}0.028^{* * *} \\
(0.006)\end{array}$ & $\begin{array}{l}0.029^{* * *} \\
(0.006)\end{array}$ & - \\
\hline R-squared & 0.930 & 0.930 & 0.930 & 0.965 \\
\hline Observations & 215,476 & 215,476 & 215,476 & 154,760 \\
\hline Firm-product-time fixed effects & Yes & Yes & Yes & Yes \\
\hline Firm-destination-time fixed effects & No & No & No & Yes \\
\hline
\end{tabular}

Notes: The dependent variable is the log FOB unit value of exports (in US dollars per kilogram). Robust standard errors adjusted for clustering by destination-time between parentheses. ${ }^{* *},{ }^{* *}$, and ${ }^{*}$ indicate significance at the one, five, and ten percent levels.

\subsection{Export Volumes}

Our model holds predictions for the effects of distance and tariffs on exports across quality levels. Using equations (5) and (6), the elasticities of export quantities $q_{i j}$ with respect to $T_{i j}$ and $\tau_{i j}$ are:

$$
\begin{aligned}
\epsilon_{T}^{q} & =\frac{-\sigma}{\left(1+\frac{c_{i}(\theta)}{T_{i j} / \tau_{i j}}\right)}<0, \\
\epsilon_{\tau}^{q} & =\frac{-\sigma}{\left(1+\frac{T_{i j} / \tau_{i j}}{c_{i}(\theta)}\right)}<0 .
\end{aligned}
$$

Quantities fall with $T_{i j}$ (and therefore with distance), especially for lower quality exports. Instead, quantities fall with $\tau_{i j}$ (and thus with tariffs), but to a larger extent for higher quality exports. ${ }^{25}$ To investigate those predictions, we estimate the following reduced-form regression:

$$
\begin{aligned}
\ln q_{i j k, t}= & \xi_{1} \ln \text { dist }_{j}+\xi_{2} \ln \text { dist }_{j} \times \text { quality }_{k}+\xi_{3} \ln \operatorname{tar}_{j, t}+\xi_{4} \ln \text { tar }_{j, t} \times \text { quality }_{k} \\
& +\xi_{5} z_{j, t}+D_{k, t}+\nu_{i j k, t},
\end{aligned}
$$

where $q_{i j k, t}$ is the export volume (in liters), and we expect $\xi_{1}+\left(\xi_{2} \times\right.$ quality $\left.{ }_{k}\right)<0$ with $\xi_{2}>0$, and $\xi_{3}+\left(\xi_{4} \times\right.$ quality $\left.k\right)<0$ with $\xi_{4}<0$. As estimations that include positive trade flows only suffer from a selection bias, we regress $q_{i j k, t}$ by Poisson Pseudo-Maximum Likelihood (Head and Mayer, 2014; Santos

\footnotetext{
${ }^{25}$ Exports fall with the CIF price (equation 5), and hence with distance and tariffs (equation 6). Distance increases the CIF price directly but also indirectly through the FOB price. As the FOB price rises less for higher quality goods, their exports fall less compared to lower quality exports. Tariffs increase the CIF price directly but also reduce it by lowering the FOB price. As the FOB price falls less for higher quality goods, their exports fall more than lower quality exports.
} 
Silva and Tenreyro, 2006). We construct a balanced sample of all possible firm-wine-destination-time combinations that includes positive and zero trade flows, and for each wine we drop the years prior to its vintage year.

Table 12: Export Volumes

\begin{tabular}{|c|c|c|c|c|c|c|}
\hline & $(1)$ & $(2)$ & $(3)$ & $(4)$ & $(5)$ & $(6)$ \\
\hline ln distance & $\begin{array}{l}-1.036^{* * *} \\
(0.069)\end{array}$ & $\begin{array}{l}-2.399^{* * *} \\
(0.372)\end{array}$ & - & $\begin{array}{l}-0.352^{* * *} \\
(0.033)\end{array}$ & $\begin{array}{l}-0.858^{* * *} \\
(0.267)\end{array}$ & - \\
\hline ln distance $\times$ quality & - & $\begin{array}{l}0.016^{* * *} \\
(0.004)\end{array}$ & $\begin{array}{l}0.018^{* * *} \\
(0.006)\end{array}$ & - & $\begin{array}{l}0.006^{*} \\
(0.003)\end{array}$ & $\begin{array}{c}-0.004 \\
(0.003)\end{array}$ \\
\hline ln tariffs & $\begin{array}{l}-2.346^{* * *} \\
(0.245)\end{array}$ & $\begin{array}{l}8.098^{* * *} \\
(2.329)\end{array}$ & - & $\begin{array}{c}-0.394^{* *} \\
(0.158)\end{array}$ & $\begin{array}{l}8.632^{* * *} \\
(1.631)\end{array}$ & - \\
\hline ln tariffs $\times$ quality & - & $\begin{array}{l}-0.124^{* * *} \\
(0.028)\end{array}$ & $\begin{array}{l}-0.219^{* * *} \\
(0.028)\end{array}$ & - & $\begin{array}{l}-0.106^{* * *} \\
(0.019)\end{array}$ & $\begin{array}{c}-0.079^{* * *} \\
(0.017)\end{array}$ \\
\hline ln remoteness & $\begin{array}{l}-0.713^{* * *} \\
(0.109)\end{array}$ & )$^{-0.713^{* * *}}$ & - & $\begin{array}{c}-0.084 \\
(0.056)\end{array}$ & $\begin{array}{c}-0.081 \\
(0.056)\end{array}$ & - \\
\hline $\ln$ GDP & $\begin{array}{l}0.737^{* * *} \\
(0.019)\end{array}$ & $\begin{array}{l}0.737^{* * *} \\
(0.019)\end{array}$ & - & $\begin{array}{l}0.281^{* * *} \\
(0.009)\end{array}$ & $\begin{array}{l}0.282^{* * *} \\
(0.009)\end{array}$ & - \\
\hline $\ln$ GDP/cap & $\begin{array}{l}0.942^{* * *} \\
(0.062)\end{array}$ & $\begin{array}{l}0.942^{* * *} \\
(0.061)\end{array}$ & - & $\begin{array}{l}0.413^{* * *} \\
(0.034)\end{array}$ & $\begin{array}{l}0.413^{* * *} \\
(0.034)\end{array}$ & - \\
\hline R-squared & - & - & - & 0.555 & 0.555 & 0.778 \\
\hline Observations & $2,472,069$ & $2,472,069$ & 421,691 & 71,952 & 71,952 & 66,941 \\
\hline Estimation & PPML & PPML & PPML & OLS & OLS & OLS \\
\hline Zero observations included & Yes & Yes & Yes & No & No & No \\
\hline Product-time fixed effects & Yes & Yes & Yes & Yes & Yes & Yes \\
\hline Firm-destination-time fixed effects & No & No & Yes & No & No & Yes \\
\hline
\end{tabular}

Notes: The dependent variable is the FOB export volume (in liters) in (1) to (3), and the log FOB export volume in (4) to (6). Robust standard errors adjusted for clustering by destination-time between parentheses. ${ }^{* * *},{ }^{* *}$, and ${ }^{*}$ indicate significance at the one, five, and ten percent levels.

Columns (1) to (3) of Table 12 report PPML estimates. Export volumes fall with distance and tariffs (column 1). The magnitude of the distance elasticity falls with quality, while the magnitude of the tariff elasticity increases with quality (column 2). This heterogeneity across quality levels remains robust to including firm-destination-time fixed effects (column 3). Besides, firms export more to richer and larger markets, and less to remote destinations. For comparison, columns (4) to (6) report OLS estimates. The coefficients tend to be smaller in magnitude but their signs and significance remain similar (except for remoteness and for the interaction between distance and quality in column 6).

According to the estimates of column (2), at the mean, $5^{t h}$, and $95^{t h}$ percentiles of the quality distribution, the distance elasticity is equal to $-1.040,-1.142$, and -0.932 , while the tariff elasticity is equal to $-2.314,-1.540$, and -3.147 , respectively (all significant at the one percent level).

\section{Robustness}

We report in Appendix F a number of robustness exercises on the estimation of equation (15). Overall, the patterns we find are supportive of our main conclusions.

Table F1 reports results using different samples and specifications. Column (1) shows that our results continue to hold once we include wholesalers and retailers in the sample (the share of wine 
exports handled by intermediaries is only equal to 4.80 percent in 2002 and to 5.33 percent in 2009). As each wine can be exported by more than one firm we now control for firm-product-time fixed effects.

In wine producing countries, wine producers may lobby for protectionism if import competition is strong. Therefore, tariffs may be endogenous. In column (2) we instrument the interaction of tariffs with quality with the (logarithm of one plus) each country's total wine production interacted with quality. The Kleibergen-Paap F statistic (equal to 83, Stock and Yogo, 2005) rejects the null of weak correlation between the instrument and the endogenous regressor.

In December 2001, as Argentina was in the midst of a crisis, the government froze all bank accounts and prohibited withdrawals from US dollar-denominated accounts. These measures lasted for a year and the lack of cash availability caused numerous problems for businesses. The fixed exchange rate was abandoned, leading to a large depreciation of the peso, and default was declared on most of the country's debt. To account for these events in column (3) we exclude the year 2002 from our sample.

The distance shipped by a given wine to a given country may vary depending on the port of exit from Argentina. As our data set reports the port of exit for each wine, we construct a new sample and we define a wine product according to its name, grape, type, vintage year, packaging type, and port of exit. As shown in column (4), controlling for the port of exit does not alter our conclusions. In column (5) we control for export volumes and their interaction with quality. This addresses the possibility that the pricing strategies of exporters depend on shipment size. In column (6) we compute unit values at annual frequency as combining quarterly data for export prices with annual data on tariffs may downward bias the standard errors (Manova and Zhang, 2012). In column (7) we include the small shipments with less than 4.5 liters in the sample.

Table F2 addresses the measurement of quality. In column (1) quality is measured using the Parker ratings. In column (2) quality is rescaled to vary between one and six. Each value corresponds to one the Wine Spectator bins (Table 1), and a larger value indicates a higher quality. Column (3) excludes "Great" wines from the sample. Column (4) excludes the US from the sample because the Wine Spectator (and Parker) is a US-based rating and may not capture taste preferences for quality in other countries. As endogeneity could arise due to measurement error in the quality ratings (Chen and Juvenal, 2016, 2018), in column (5) we use the Parker scores to instrument the Wine Spectator ratings (both interacted with distance and tariffs) under the assumption that their measurement errors are uncorrelated. The Kleibergen-Paap F statistic (equal to 404, Stock and Yogo, 2005) rejects the null of weak correlation between the instruments and the endogenous regressors.

Based on the Khandelwal (2010) methodology (see Appendix E), we also estimate quality for each 12-digit HS-level wine product exported by each firm to each country in each time period. Our sample size more than doubles as many unrated wines can be included in the sample. As shown in column (6), our results continue to hold. In column (7) we interact distance and tariffs with both estimated quality and the Wine Spectator ratings. The coefficients on both sets of interactions remain significant and with expected signs, although the ones on the interactions with estimated quality become less 
significant. This finding most likely reflects the fact that the Khandelwal (2010) measure embodies not only quality but also consumer tastes.

To check if our results hold for both lower and higher quality wines, in column (8) we classify the "Very good," "Outstanding," and "Great" wines as high quality, the "Not recommended," "Mediocre," and "Good" ones as low quality, and we estimate different coefficients for the two quality categories.

Finally, in Table F3 we estimate the cross-sectional variation of our coefficients. We estimate equation (14) and we interact the distance and tariff variables with year dummies. For the years 20042009, markups rise with distance, fall with tariffs, and these effects are stronger in magnitude for lower quality exports. The insignificant results for 2002 and 2003 could be due to the economic crisis of 2002 (see above), or to the poorer data coverage compared to the other years (see Table 2).

\section{Concluding Remarks}

Guided by the predictions of a model that features endogenous markups and per unit trade costs, our paper is the first to provide robust empirical evidence that exporters adjust their markups across destinations depending on trade costs such as distance and tariffs. Firms raise their markups in more distant markets, but lower them in high-tariff countries. Moreover, the effects of trade costs on markups are heterogeneous and are smaller in magnitude for higher quality exports. This heterogeneity is stronger for exports to richer countries, and it is predominantly driven by the higher quality firms, the larger firms, and the exporters with larger export market shares. As these high performance firms tend to charge higher markups, they are better able to adjust them across countries and quality levels in response to changes in trade costs.

Our results are important because they show that the variation in firm-level export prices across markets is not only driven by quality differences but also by markup variation conditional on quality. Due to market power, firms thus price discriminate across destinations, but the way and the extent to which they do so depends on the size and on the nature of trade costs (i.e., per unit versus ad valorem), and on the quality they export. Trade costs therefore play a key role in generating deviations from the Law of One Price, and they thus matter in explaining the degree of international market segmentation. And as our results are mainly driven by the high performance firms that contribute to the bulk of aggregate exports, they can be expected to matter in explaining aggregate export prices and markups.

Our findings imply that trade models assuming that markups are invariant to country-level characteristics lack a key channel to explain the pricing strategies of exporters across international markets. Our results therefore militate in favor of trade models featuring variable markups that depend on trade costs. They also emphasize the importance of modelling trade costs more flexibly, and in particular that accounting for per unit trade costs enables us to explain strong patterns observed in the data. We believe that understanding the welfare implications of our results would be an important next step. ${ }^{26}$

\footnotetext{
${ }^{26}$ Irarrazabal et al. (2015) and Lashkaripour (2017) show that the welfare gains from trade are larger in models with per unit trade costs. Fan, Li, Xu, and Yeaple (2017) instead argue that they are lower.
} 


\section{References}

Alchian, A.A., Allen, W.R., 1964. University Economics. Wadsworth Publishing, Belmont, California.

Amiti, M., Itskhoki, O., Konings, J., 2014. Importers, exporters, and exchange rate disconnect. American Economic Review 104 (7), 1942-1978.

Amiti, M., Itskhoki, O., Konings, J., 2019. International shocks, variable markups and domestic prices. Review of Economic Studies, forthcoming.

Anderson, K., Nelgen, S., 2011. Global Wine Markets, 1961-2009: A Statistical Compendium. University of Adelaide Press, Adelaide.

Arkolakis, C., Costinot, A., Donaldson, D., Rodríguez-Clare, A., 2019. The elusive pro-competitive effects of trade. Review of Economic Studies 86 (1), 46-80.

Atkeson, A., Burstein, A., 2008. Trade costs, pricing-to-market, and international relative prices. American Economic Review 98 (5), 1998-2031.

Atkin, D., Donaldson, D., 2015. Who's getting globalized? The size and implications of intra-national trade costs, mimeo.

Atkin, D., Khandelwal, A.K., Osman, A., 2017. Exporting and firm performance: evidence from a randomized experiment. Quarterly Journal of Economics 132 (2), 551-615.

Baldwin, R.E., Harrigan, J., 2011. Zeros, quality, and space: trade theory and trade evidence. American Economic Journal: Microeconomics 3 (2), 60-88.

Bastos, P., Silva, J., 2010. The quality of a firm's exports: where you export to matters. Journal of International Economics 82 (2), 99-111.

Behrens, K., Murata, Y., 2007. General equilibrium models of monopolistic competition: a new approach. Journal of Economic Theory 136 (1), 776-787.

Bellone, F., Musso, P., Nesta, L., Warzynski, F., 2014. International trade and firm-level markups when location and quality matter. Journal of Economic Geography 16 (1), 67-91.

Berman, N., Martin, P., Mayer, T., 2012. How do different exporters react to exchange rate changes? Quarterly Journal of Economics 127 (1), 437-492.

Bernini, M., Tomasi, C., 2015. Exchange rate pass-through and product heterogeneity: does quality matter on the import side? European Economic Review 77, 117-138.

Bosker, M., Buringh, E., 2019. Iceberg transport costs. Evidence from the $19^{\text {th }}$ century ice trade. Economic Journal, forthcoming.

Broda, C., Weinstein, D.E., 2006. Globalization and the gains from variety. Quarterly Journal of Economics 121 (2), 541-585. 
Cavallo, A., Gopinath, G., Neiman, B., Tang, J., 2019. Tariff passthrough at the border and at the store: evidence from US trade policy, mimeo.

Chen, N., Imbs, J., Scott, A., 2009. The dynamics of trade and competition. Journal of International Economics 77 (1), 50-62.

Chen, N., Juvenal, L., 2016. Quality, trade, and exchange rate pass-through. Journal of International Economics 100, 61-80.

Chen, N., Juvenal, L., 2018. Quality and the Great Trade Collapse. Journal of Development Economics $135,59-76$.

Crinò, R., Epifani, P., 2012. Productivity, quality, and export behaviour. Economic Journal 122 (565), 1206-1243.

Crozet, M., Head, K., Mayer, T., 2012. Quality sorting and trade: firm-level evidence for French wine. Review of Economic Studies 79 (2), 609-644.

Daudin, G., Héricourt, J., Patureau, L., 2018. International transport costs: new findings from modelling additive costs. CEPII Working Paper 2018-10.

De Loecker, J., Goldberg, P.K., Khandelwal, A.K., Pavcnik, N., 2016. Prices, markups, and trade reform. Econometrica 84 (2), 445-510.

De Loecker, J., Warzynski, F., 2012. Markups and firm-level export status. American Economic Review 102 (6), 2437-2471.

Eaton, J., Kortum, S., 2002. Technology, geography and trade. Econometrica 70 (5), 1741-1779.

Emlinger, C., Lamani, V., 2017. International trade, quality sorting and trade costs: the case of Cognac. CEPII Working Paper 2017-18.

Fajgelbaum, P., Grossman, G.M., Helpman, E., 2011. Income distribution, product quality, and international trade. Journal of Political Economy 119 (4), 721-765.

Fan, H., Li, Y.A., Xu, S., Yeaple, S.R., 2017. Quality, variable markups, and welfare: a quantitative general equilibrium analysis of export prices, mimeo.

Feenstra, R.C., 1994. New product varieties and the measurement of international prices. American Economic Review 84 (1), 157-177.

Feenstra, R.C., 2003. A homothetic utility function for monopolistic competition models, without constant price elasticity. Economics Letters 78 (1), 79-86.

Feenstra, R.C., Romalis, J., 2014. International prices and endogenous quality. Quarterly Journal of Economics 129 (2), 477-527. 
Fitzgerald, D., Haller, S., 2014. Pricing-to-market: evidence from plant-level prices. Review of Economic Studies 81 (2), 761-786.

Gaulier, G., Zignago, S., 2010. BACI: International trade database at the product-level. The 1994-2007 version. CEPII Working Paper 2010-23.

Görg, J., Halpern, L., Muraközy, B., 2017. Why do within-firm-product export prices differ across markets? Evidence from Hungary. The World Economy 40 (6), 1233-1246.

Greenhut, M.L., Ohta, H., Sailors, J., 1985. Reverse dumping: a form of spatial price discrimination. Journal of Industrial Economics 34 (2), 167-181.

Hallak, J.C., 2006. Product quality and the direction of trade. Journal of International Economics 68 (1), 238-265.

Harrigan, J., Ma, X., Shlychkov, V., 2015. Export prices of US firms. Journal of International Economics 97 (1), 100-111.

Head, K., Mayer, T., 2014. Gravity equations: workhorse, toolkit, and cookbook, in: Gopinath, G., Helpman, E., Rogoff, K. (Eds), Handbook of International Economics, Vol. 4, Elsevier, Amsterdam, pp. 131-195.

Hoover, E.M., 1937. Spatial price discrimination. Review of Economic Studies 4 (3), 182-191.

Hummels, D., Klenow, P.J., 2005. The variety and quality of a nation's exports. American Economic Review 95 (3), 704-723.

Hummels, D., Skiba, A., 2004. Shipping the good apples out? An empirical confirmation of the AlchianAllen conjecture. Journal of Political Economy 112 (6), 1384-1402.

Imbs, J., Méjean, I., 2015. Elasticity optimism. American Economic Journal: Macroeconomics 7 (3), $43-83$.

Irarrazabal, A., Moxnes, A., Opromolla, L.D., 2015. The tip of the iceberg: a quantitative framework for estimating trade costs. Review of Economics and Statistics 97 (4), 777-792.

Johnson, R.C., 2012. Trade and prices with heterogeneous firms. Journal of International Economics $86(1), 43-56$.

Khandelwal, A., 2010. The long and short (of) quality ladders. Review of Economic Studies 77 (4), 1450-1476.

Krugman, P., 1980. Scale economies, product differentiation, and the pattern of trade. American Economic Review 70 (5), 950-959.

Kugler, M., Verhoogen, E., 2012. Prices, plant size, and product quality. Review of Economic Studies 79 (1), 307-339. 
Lashkaripour, A., 2017. The international gains from declining transport costs, mimeo.

Lugovskyy, V., Skiba, A., 2015. How geography affects quality. Journal of Development Economics 115, $156-180$.

Lugovskyy, V., Skiba, A., 2016. Positive and negative effects of distance on export prices. Journal of Economic Behavior and Organization 127, 155-181.

Manova, K., Zhang, Z., 2012. Export prices across firms and destinations. Quarterly Journal of Economics 127 (1), 379-436.

Martin, J., 2010. Markups, quality, and transport costs. CREST Working Paper 2010-17.

Martin, J., 2012. Markups, quality, and transport costs. European Economic Review 56 (4), 777-791.

Medina, P., 2018. Import competition, quality upgrading and exporting: evidence from the Peruvian apparel industry, mimeo.

Melitz, M.J., 2003. The impact of trade on intra-industry reallocations and aggregate industry productivity. Econometrica 71 (6), 1695-1725.

Melitz, M.J., Ottaviano, G.I.P., 2008. Market size, trade, and productivity. Review of Economic Studies 75 (1), 295-316.

Ottaviano, G., Tabuchi, T., Thisse, J.-F., 2002. Agglomeration and trade revisited. International Economic Review 43 (2), 409-435.

Piveteau, P., Smagghue, G., 2019. Estimating firm product quality using trade data. Journal of International Economics 118, 217-232.

Santos Silva, J.M.C., Tenreyro, S., 2006. The log of gravity. Review of Economics and Statistics 88 (4), 641-658.

Schott, P.K., 2004. Across-product versus within-product specialization in international trade. Quarterly Journal of Economics 119 (2), 647-678.

Simonovska, I., 2015. Income differences and prices of tradables: insights from an online retailer. Review of Economic Studies 82 (4), 1612-1656.

Stock, J.H., Yogo, M., 2005. Testing for weak instruments in linear IV regression, in: Andrews, D.W.K., Stock, J.H. (Eds), Identification and Inference for Econometric Models: Essays in Honor of Thomas Rothenberg. Cambridge University Press, Cambridge, pp. 80-108.

Takechi, K., 2015. The quality of distance: quality sorting, Alchian-Allen effect, and geography. RIETI Discussion Paper 15-E-018.

Verhoogen, E., 2008. Trade, quality upgrading and wage inequality in the Mexican manufacturing sector. Quarterly Journal of Economics 123 (2), 489-530. 


\section{A Per Unit versus Ad Valorem Trade Costs}

We provide evidence that both per unit and ad valorem trade costs are pervasive in our data. Also, consistent with the premise that per unit trade costs increase with distance, we show that trade costs become more per unit than ad valorem as distance increases.

First, to identify the nature of trade costs in our data, we estimate the following reduced-form regression (Hummels and Skiba, 2004; Lashkaripour, 2017; Lugovskyy and Skiba, 2015):

$$
\ln f_{i j k, t}=\psi_{1} \ln u v_{i j k, t}+\psi_{2} \ln d i s t_{j}+\psi_{3} \ln q_{i j k, t}+D_{i, t}+D_{p}+\mu_{i j k, t},
$$

where for each wine product $k$ exported by firm $i$ to country $j$ in quarter $t, f_{i j k, t}$ are freight charges divided by the volume exported (in US dollars per liter), $u v_{i j k, t}$ is the export unit value (in US dollars per liter), dist ${ }_{j}$ is the bilateral distance between Argentina and country $j$, and $q_{i j k, t}$ is shipment size (in liters). We expect freight costs to increase with distance. Freight costs should also increase with export prices as more expensive goods may require heavier packaging, more careful and costly handling, and face higher insurance fees (Hummels and Skiba, 2004). Instead, freight costs should fall with shipment size if there are scale economies in transportation (i.e., it should be less costly to export a large shipment at once than many small shipments at different times).

The coefficient of interest is $\psi_{1}$ as it captures the extent to which freight costs are ad valorem or per unit. If freight costs are ad valorem only, they vary proportionally with export prices such that $\psi_{1}=1$. If they are per unit only, they do not depend on export prices such that $\psi_{1}=0$. An elasticity $\psi_{1}$ between zero and unity in turn indicates that freight costs are both per unit and ad valorem, and the smaller the elasticity, the larger the per unit component of freight costs. As we want to identify the effect of unit values (and not of markups) on freight costs, we include firm-time $D_{i, t}$ and product characteristics $D_{p}$ (grape, type, vintage year, HS-level, packaging, and province of origin) fixed effects (the results remain similar if we instead include product-time fixed effects). Robust standard errors are adjusted for clustering by destination-time.

One issue is that unit values and shipment size are endogenous to freight costs. Freight costs rise with prices because of higher insurance or handling requirements, but prices increase with freight costs if they have a per unit component (see equation 7 ), resulting in a positive endogeneity bias. We therefore instrument, in each time period, the unit value of each wine product exported to a given country with its mean unit value on exports to other destinations. The mean unit value is exogenous by construction as it excludes the unit value to be instrumented. Besides, as the dependent variable divides freight charges by the volume exported, it is negatively correlated with shipment size. We use the destination's GDP and GDP per capita to instrument export volumes (Hummels and Skiba, 2004).

Our data set reports freight charges (in US dollars) at the firm-product-destination-time level. As the coverage is very incomplete, the sample we use to estimate equation (A1) only includes 107 firms, 1,440 wines (1,534 products), and 82 export markets between 2005Q4 and 2009Q4 (6,802 observations). 
Column (1) of Table A1 reports OLS estimates. Freight costs rise with distance and fall with export volumes. They also increase with unit values and the elasticity is equal to 0.758 (significantly lower than unity at the one percent level). Column (2) instruments unit values and the elasticity falls to 0.713 (the OLS estimate in column 1 is therefore upward biased). Column (3) also instruments shipment size and the unit value elasticity falls to $0.667 .{ }^{27}$ Freight costs are thus both per unit and ad valorem.

Table A1: Per Unit versus Ad Valorem Trade Costs

\begin{tabular}{|c|c|c|c|c|c|c|}
\hline & (1) & $(2)$ & (3) & (4) & $(5)$ & (6) \\
\hline ln unit value & $\begin{array}{l}0.758^{* * *} \\
(0.032)\end{array}$ & $\begin{array}{l}0.713^{* * *} \\
(0.043)\end{array}$ & $\begin{array}{l}0.667^{* * *} \\
(0.048)\end{array}$ & $\begin{array}{l}1.285^{* * *} \\
(0.299)\end{array}$ & $\begin{array}{l}1.659^{* * *} \\
(0.304)\end{array}$ & $\begin{array}{l}1.512^{* * *} \\
(0.304)\end{array}$ \\
\hline ln distance & $\begin{array}{l}0.062^{* *} \\
(0.031)\end{array}$ & $\begin{array}{l}0.069^{* *} \\
(0.030)\end{array}$ & $\begin{array}{l}0.068^{* *} \\
(0.030)\end{array}$ & $\begin{array}{l}0.152^{* * *} \\
(0.058)\end{array}$ & $\begin{array}{l}0.228^{* * *} \\
(0.062)\end{array}$ & $\begin{array}{l}0.210^{* * *} \\
(0.062)\end{array}$ \\
\hline $\ln$ unit value $\times \ln$ distance & - & - & - & $\begin{array}{c}-0.059^{*} \\
(0.034)\end{array}$ & $\begin{array}{l}-0.107^{* * *} \\
(0.035)\end{array}$ & $\begin{array}{c}-0.096^{* * *} \\
(0.035)\end{array}$ \\
\hline ln export volume & $\begin{array}{l}-0.121^{* * *} \\
(0.012)\end{array}$ & $\begin{array}{l}-0.133^{* * *} \\
(0.014)\end{array}$ & $\begin{array}{l}-0.187^{* * *} \\
(0.022)\end{array}$ & $\begin{array}{l}-0.120^{* * *} \\
(0.012)\end{array}$ & $\begin{array}{l}-0.132^{* * *} \\
(0.014)\end{array}$ & $\begin{array}{l}-0.186^{* * *} \\
(0.022)\end{array}$ \\
\hline \multicolumn{7}{|l|}{ Unit value elasticities } \\
\hline Mean & - & - & - & $\begin{array}{l}0.756^{* * *} \\
(0.033)\end{array}$ & $\begin{array}{l}0.702^{* * *} \\
(0.043)\end{array}$ & $\begin{array}{l}0.656^{* * *} \\
(0.048)\end{array}$ \\
\hline $5^{t h}$ percentile & - & - & - & $\begin{array}{l}0.810^{* * *} \\
(0.039)\end{array}$ & $\begin{array}{l}0.800^{* * *} \\
(0.045)\end{array}$ & $\begin{array}{l}0.744^{* * * *} \\
(0.049)\end{array}$ \\
\hline $95^{\text {th }}$ percentile & - & - & - & $\begin{array}{l}0.702^{* * * *} \\
(0.051)\end{array}$ & $\begin{array}{l}0.604^{* * *} \\
(0.061)\end{array}$ & $\begin{array}{l}0.569^{* * * *} \\
(0.065)\end{array}$ \\
\hline R-squared & 0.660 & 0.299 & 0.287 & 0.660 & 0.301 & 0.289 \\
\hline Observations & 6,706 & 5,116 & 5,116 & 6,706 & 5,116 & 5,116 \\
\hline Estimation & OLS & IV & IV & OLS & IV & IV \\
\hline Kleibergen-Paap F & - & 346.35 & 196.90 & - & 143.25 & 147.73 \\
\hline
\end{tabular}

Notes: The dependent variable is the log freight cost per liter exported (in US dollars per liter). Firm-time and product characteristics (grape, type, vintage year, HS-level, packaging, and province of origin) fixed effects are included. Robust standard errors adjusted for clustering by destination-time between parentheses. ${ }^{* * *},{ }^{* *}$, and ${ }^{*}$ indicate significance at the one, five, and ten percent levels. In (2), (3), (5), and (6), unit values are instrumented with mean unit values. In (5) and (6), the interaction term is instrumented with mean unit values interacted with distance. In (3) and (6), shipment size is instrumented with the destination's GDP and GDP per capita.

Second, we follow Lugovskyy and Skiba (2015) and we add to equation (A1) an interaction term between unit values and distance. If freight costs become more per unit than ad valorem at longer distances, the coefficient on the interaction term should be negative.

Column (4) reports OLS results, and the coefficient on the interaction term is negative. It remains negative once we instrument unit values and the interaction term with mean unit values and their interaction with distance (column 5), and when we also instrument shipment size (column 6). Therefore, freight costs become more per unit than ad valorem at longer distances. At the mean value of distance, the unit value elasticity in column (6) is equal to 0.656 . It is equal to 0.744 at the $5^{\text {th }}$ percentile of the distance distribution, and falls to 0.569 at the $95^{\text {th }}$ percentile (all elasticities are significantly lower than unity at the one percent level). Based on the Kleibergen-Paap F statistic, we reject in columns (5) and (6) the null of weak correlation between the instruments and the endogenous regressors.

\footnotetext{
${ }^{27}$ Unit values increase with mean unit values while shipment size increases with GDP and GDP per capita. The Kleibergen-Paap F statistic rejects the null of weak correlation between the instruments and the endogenous regressors.
} 


\section{B Alternative Demand Systems}

Irarrazabal et al. (2015) predict that higher per unit trade costs reduce the magnitude of the elasticity of demand to the FOB price $\epsilon^{f o b}$, especially among low-price firms. They investigate whether this mechanism holds for different demand systems. We review their findings and we extend their analysis to examine how $\epsilon^{f o b}$ varies with ad valorem trade costs and the FOB price.

As in Irarrazabal et al. (2015), consider a general demand system for differentiated goods (Arkolakis, Costinot, Donaldson, and Rodríguez-Clare, 2019). All consumers have the same preferences. For a consumer with income $y$ facing a vector of prices $\mathbf{p}$, her Marshallian demand for any good is:

$$
\ln q\left(p^{c i f}, p^{*}, y\right)=-\beta \ln p^{c i f}+\gamma \ln y+f\left(\ln p^{c i f}-\ln p^{*}\right)
$$

where $q$ and $p^{c i f}$ are quantity and CIF price, $p^{c i f}=\tau p^{f o b}+T$ where $p^{f o b}$ is the FOB price and $\tau$ and $T$ are the ad valorem and per unit components of trade costs, respectively, and $p^{*}(\mathbf{p})$ is a price index which is symmetric in all prices $\mathbf{p}$. All other prices therefore affect demand only through their effect on the price aggregator $p^{*}$. Denoting $s=\ln p^{c i f}-\ln p^{*}<0$, this framework encompasses four different utility functions that have been widely used in the literature: (a) CES utility, in which case $\gamma=\beta=1$ and $f(s)=(1-\sigma) s$; (b) quadratic, non-separable utility (Ottaviano et al., 2002), in which case $\gamma=0$, $\beta=-1$, and $f(s)=-\ln \kappa_{2}+\ln \left(e^{-s}-1\right)$; (c) translog preferences (Feenstra, 2003), in which case $\gamma=\beta=1$ and $f(s)=\ln \xi+\ln (-s)$; and (d) additively quasi-separable utility (Behrens and Murata, 2007), in which case $\gamma=\beta=0$ and $f(s)=\ln \zeta+\ln (-s)$.

\section{B.1 Per Unit Trade Costs}

For all four demand systems, Irarrazabal et al. (2015) calculate the elasticity of demand with respect to the FOB price $\epsilon^{f o b}$ for $T=0$ or $T>0$. As shown in rows (1) and (2) of Table B1, whether $T=0$ or $T>0$ all demand systems yield $\epsilon^{f o b}<0$.

In a next step, they derive the elasticity of $\epsilon^{f o b}$ with respect to per unit trade costs. As shown in row (3), this elasticity is negative with CES, translog, and additively quasi-separable utility (for some values of $s$ ), while it is positive with quadratic preferences. Row (4) shows that the elasticity of $\epsilon^{f o b}$ with respect to per unit trade costs is in all cases increasing with the FOB price. See Irarrazabal et al. (2015) for the full derivations. We discuss the implications of these findings further below.

\section{B.2 Ad Valorem Trade Costs}

We extend the analysis to the case of ad valorem trade costs. In rows (5) and (6) of Table B1, we calculate $\epsilon^{f o b}$ for $\tau=1$ or $\tau>1$, respectively, assuming that $T>0$. Whether $\tau=1$ or $\tau>1$, all demand systems yield $\epsilon^{f o b}<0 .{ }^{28}$

\footnotetext{
${ }^{28}$ The elasticities in rows (2) and (6) both correspond to the case where $T>0$ and $\tau>1$ and they are hence identical.
} 
The prediction that export prices fall with ad valorem trade costs, especially for low-price/lowquality exports, requires the elasticity of $\epsilon^{f o b}$ with respect to ad valorem trade costs to be positive and decreasing with the FOB price. For each demand system, we calculate the elasticity of $\epsilon^{f o b}$ with respect to ad valorem trade costs and we determine its sign. We then show how this elasticity changes with the FOB price. Rows (7) and (8) of Table B1 provide a summary of our results.

CES preferences The elasticity of $\epsilon^{f o b}$ with respect to ad valorem trade costs is:

$$
\frac{\partial \epsilon^{f o b}}{\partial \tau} \frac{\tau}{\epsilon^{f o b}}=\frac{T}{\tau p^{f o b}+T}>0
$$

and it decreases with the FOB price:

$$
\frac{\partial}{\partial p^{f o b}}\left(\frac{\partial \epsilon^{f o b}}{\partial \tau} \frac{\tau}{\epsilon^{f o b}}\right)=\frac{-T \tau}{\left(\tau p^{f o b}+T\right)^{2}}<0 .
$$

Quadratic, non-separable utility The elasticity of $\epsilon^{f o b}$ with respect to ad valorem trade costs is:

$$
\frac{\partial \epsilon^{f o b}}{\partial \tau} \frac{\tau}{\epsilon^{f o b}}=\frac{T-p^{*}}{p^{c i f}-p^{*}}>0
$$

because $p^{c i f}-p^{*}<0$ as $s=\ln p^{c i f}-\ln p^{*}<0$, and $T-p^{*}<-\tau p^{f o b}<0$ as $\ln p^{c i f}-\ln p^{*}=$ $\ln \left(\tau p^{f o b}+T\right)-\ln p^{*}<0$.

The elasticity of $\epsilon^{f o b}$ with respect to ad valorem trade costs increases with the FOB price:

$$
\frac{\partial}{\partial p^{f o b}}\left(\frac{\partial \epsilon^{f o b}}{\partial \tau} \frac{\tau}{\epsilon^{f o b}}\right)=\frac{-\left(T-p^{*}\right) \tau}{\left(\tau p^{f o b}-p^{*}+T\right)^{2}}>0,
$$

because $-\left(T-p^{*}\right) \tau>0$ as $T-p^{*}<0$.

Translog preferences The elasticity of $\epsilon^{f o b}$ with respect to ad valorem trade costs is:

$$
\frac{\partial \epsilon^{f o b}}{\partial \tau} \frac{\tau}{\epsilon^{f o b}}=\frac{s^{2} T-s T+\tau p^{f o b}}{-s p^{c i f}(1-s)}>0
$$

We know that $-s p^{c i f}(1-s)>0$ because $s<0$. In the numerator, the roots of $s^{2} T-s T+\tau p^{f o b}$ are $\left(T \pm \sqrt{T^{2}-4 T \tau p^{f o b}}\right) / 2 T$. As the function is strictly convex, it is always positive for $s<0$ whether the discriminant is positive (two positive roots), negative (no real roots), or zero (one positive root). The numerator of (B6) is therefore positive.

The elasticity of $\epsilon^{f o b}$ with respect to ad valorem trade costs decreases with the FOB price. By the chain rule we know that:

$$
\frac{\partial}{\partial p^{f o b}}\left(\frac{\partial \epsilon^{f o b}}{\partial \tau} \frac{\tau}{\epsilon^{f o b}}\right)=\frac{\partial}{\partial s}\left(\frac{\partial \epsilon^{f o b}}{\partial \tau} \frac{\tau}{\epsilon^{f o b}}\right) \frac{\partial s}{\partial p^{c i f}} \frac{\partial p^{c i f}}{\partial p^{f o b}}
$$


As $\partial s / \partial p^{c i f}=1 / p^{c i f}>0$ and $\partial p^{c i f} / \partial p^{f o b}=\tau>0$, the sign of this derivative depends on the sign of $(\partial / \partial s)\left(\left(\partial \epsilon^{f o b} / \partial \tau\right)\left(\tau / \epsilon^{f o b}\right)\right)$. From (B6) we know that the denominator of $\left(\partial \epsilon^{f o b} / \partial \tau\right)\left(\tau / \epsilon^{f o b}\right)$ is always positive, and as the function in the numerator is strictly convex and reaches its minimum in the positive domain for $s=0.5$, it follows that $(\partial / \partial s)\left(\left(\partial \epsilon^{f o b} / \partial \tau\right)\left(\tau / \epsilon^{f o b}\right)\right)<0$ for $s<0$. The sign of the derivative in (B7) is therefore negative.

Additively quasi-separable utility The elasticity of $\epsilon^{f o b}$ with respect to ad valorem trade costs is:

$$
\frac{\partial \epsilon^{f o b}}{\partial \tau} \frac{\tau}{\epsilon^{f o b}}=\frac{\tau p^{f o b}-s T}{-s p^{c i f}}>0
$$

because $-s p^{c i f}>0$ and $\tau p^{f o b}-s T>0$ as $s<0$.

The elasticity of $\epsilon^{f o b}$ with respect to ad valorem trade costs changes with the FOB price according to:

$$
\frac{\partial}{\partial p^{f o b}}\left(\frac{\partial \epsilon^{f o b}}{\partial \tau} \frac{\tau}{\epsilon^{f o b}}\right)=\frac{-\tau\left(T s^{2}+T s-\tau p^{f o b}\right)}{\left(-\ln p^{c i f}+\ln p^{*}\right)^{2}\left(\tau p^{f o b}+T\right)^{2}} .
$$

In the numerator, the roots of $T s^{2}+T s-\tau p^{f o b}$ are $\left(-T \pm \sqrt{T^{2}+4 T \tau p^{f o b}}\right) / 2 T$. As $s<0$, the relevant root is $\left(-T-\sqrt{T^{2}+4 T \tau p^{f o b}}\right) / 2 T$. As the function is strictly convex, the numerator of (B9) is positive for $\left(-T-\sqrt{T^{2}+4 T \tau p^{f o b}}\right) / 2 T<s<0$, and negative for $s<\left(-T-\sqrt{T^{2}+4 T \tau p^{f o b}}\right) / 2 T$.

To sum up,

1. The prediction that prices and markups increase with distance requires $\left(\partial \epsilon^{f o b} / \partial T\right)\left(T / \epsilon^{f o b}\right)<0$. This condition is satisfied with CES. It also holds with translog and additively quasi-separable utility (for some values of $s$ ). It is not satisfied with quadratic preferences.

2. The prediction that the effect of distance on prices and markups is smaller in magnitude for higher price (and higher quality) exports requires $\left(\partial / \partial p^{f o b}\right)\left(\left(\partial \epsilon^{f o b} / \partial T\right)\left(T / \epsilon^{f o b}\right)\right)>0$. This condition holds in all cases.

3. The prediction that prices and markups fall with tariffs requires $\left(\partial \epsilon^{f o b} / \partial \tau\right)\left(\tau / \epsilon^{f o b}\right)>0$. This condition holds for all demand systems.

4. The prediction that the effect of tariffs on prices and markups is smaller in magnitude for higher price (and higher quality) exports requires $\left(\partial / \partial p^{f o b}\right)\left(\left(\partial \epsilon^{f o b} / \partial \tau\right)\left(\tau / \epsilon^{f o b}\right)\right)<0$. This condition is satisfied with CES, translog, and additively quasi-separable utility (for some values of $s$ ). It is not satisfied with quadratic preferences.

In other words, our predictions that (1) export prices and markups increase with distance, (2) fall with tariffs, (3) and to a larger extent for lower quality exports hold with CES, and with translog and additively quasi-separable utility (for some parameter values only). Models with quadratic, nonseparable utility can yield some, but not all, of our predictions. 
Table B1: Alternative Demand Systems

\begin{tabular}{|c|c|c|c|c|}
\hline & CES & Quadratic & Translog & Quasi-separable \\
\hline \multicolumn{5}{|l|}{ Per unit trade cost $T$} \\
\hline (1) $\epsilon^{f o b}=\left.\frac{\partial \ln q}{\partial \ln p^{f o b}}\right|_{T=0}$ & $-\sigma<0$ & $-\frac{1}{e^{-s}-1}<0$ & $\frac{1-s}{s}<0$ & $\frac{1}{s}<0$ \\
\hline (3) $\frac{\partial \epsilon^{f o b}}{\partial T} \frac{T}{\epsilon^{f o b}}$ & $<0$ & $>0$ & $\begin{array}{l}<0 \text { if } \frac{1-\sqrt{5}}{2}<s<0 \\
>0 \text { if } s<\frac{1-\sqrt{5}}{2}\end{array}$ & $\begin{array}{l}<0 \text { if } s<-1 \\
>0 \text { if }-1<s<0\end{array}$ \\
\hline (4) $\frac{\partial}{\partial p^{f o b}}\left(\frac{\partial \epsilon^{f o b}}{\partial T} \frac{T}{\epsilon^{f o b}}\right)$ & $>0$ & $>0$ & $>0$ & $>0$ \\
\hline \multicolumn{5}{|c|}{ Ad valorem trade cost $\tau$} \\
\hline (5) $\epsilon^{f o b}=\left.\frac{\partial \ln q}{\partial \ln p^{f o b}}\right|_{\tau=1}$ & $-\sigma\left(\frac{p^{f o b}}{p^{f o b}+T}\right)<0$ & $-\frac{1}{e^{-s}-1}\left(\frac{p^{f o b}}{p^{f o b}+T}\right)<0$ & $\frac{1-s}{s}\left(\frac{p^{f o b}}{p^{f o b}+T}\right)<0$ & $\frac{1}{s}\left(\frac{p^{f o b}}{p^{f o b}+T}\right)<0$ \\
\hline (6) $\epsilon^{f o b}=\left.\frac{\partial \ln q}{\partial \ln p^{f o b}}\right|_{\tau>1}$ & $-\sigma\left(1-\frac{T}{p^{c i f}}\right)<0$ & $-\frac{1}{e^{-s}-1}\left(1-\frac{T}{p^{c i f}}\right)<0$ & $\frac{1-s}{s}\left(1-\frac{T}{p^{c i f}}\right)<0$ & $\frac{1}{s}\left(1-\frac{T}{p^{c i f}}\right)<0$ \\
\hline (7) $\frac{\partial \epsilon^{f o b}}{\partial \tau} \frac{\tau}{\epsilon^{f o b}}$ & $>0$ & $>0$ & $>0$ & $>0$ \\
\hline (8) $\frac{\partial}{\partial p^{f o b}}\left(\frac{\partial \epsilon^{f o b}}{\partial \tau} \frac{\tau}{\epsilon^{f o b}}\right)$ & $<0$ & $>0$ & $<0$ & $\begin{array}{l}<0 \text { if } s<\frac{-T-\sqrt{T^{2}+4 T \tau p^{f o b}}}{2 T} \\
>0 \text { if } \frac{-T-\sqrt{T^{2}+4 T \tau p^{f o b}}}{2 T}<s<0\end{array}$ \\
\hline
\end{tabular}




\section{Elasticity of Demand to the FOB Price}

Equation (13) predicts that the elasticity of $\epsilon^{f o b}$ with respect to per unit trade costs is negative and increases with quality. It also predicts that the elasticity of $\epsilon^{f o b}$ with respect to ad valorem trade costs is positive and decreases with quality. To determine whether the two mechanisms hold in our data we estimate (Irarrazabal et al., 2015):

$$
\ln q_{i j k, t}=\Psi\left[\ln u v_{i j k, t} \times \ln d i s t_{j} \times q u a l i t y_{k}\right]+\Upsilon\left[\ln u v_{i j k, t} \times \ln \operatorname{tar}_{j, t} \times q u a l i t y_{k}\right]+D_{i j, t}+\varpi_{i j k, t},
$$

where $q_{i j k, t}$ is the export volume (in liters) of wine product $k$ exported by firm $i$ to country $j$ in quarter $t$. We include a full set of interactions between unit values, bilateral distance as a proxy for per unit trade costs, and quality. We also include a full set of interactions between unit values, tariffs as a proxy for ad valorem trade costs, and quality. The vectors of estimated coefficients are denoted by $\Psi$ and $\Upsilon$, respectively. ${ }^{29,30}$ We control for firm-destination-time fixed effects $D_{i j, t}$, and robust standard errors are adjusted for clustering at the destination-time level. The demand elasticity $\epsilon^{f o b}$ is given by:

$$
\begin{aligned}
\epsilon^{f o b}=\frac{\partial \ln q_{i j k, t}}{\partial \ln u v_{i j k, t}}= & \Psi_{1}+\Psi_{2} \ln \text { dist }_{j}+\Psi_{3} \text { quality }_{k}+\Psi_{4} \ln \text { dist }_{j} \times \text { quality }_{k}+\Upsilon_{2} \ln \text { tar }_{j, t} \\
& +\Upsilon_{4} \ln \text { tar }_{j, t} \times \text { quality }_{k} .
\end{aligned}
$$

We expect $\Psi_{2}>0$, reflecting that distance increases the negative $\epsilon^{f o b}$ (i.e., $\epsilon^{f o b}$ approaches zero), and $\Psi_{4}<0$, showing that the effect of distance on $\epsilon^{f o b}$ is smaller for higher quality exports. Likewise we expect $\Upsilon_{2}<0$, capturing that tariffs decrease the negative $\epsilon^{f o b}$ (i.e., $\epsilon^{f o b}$ becomes more negative), and $\Upsilon_{4}>0$ such that the effect of tariffs on $\epsilon^{f o b}$ is smaller for higher quality exports.

To address the endogeneity of unit values in equation (C1) we instrument, in each time period, the unit value of each wine product exported to a given country with its mean unit value on exports to other destinations (see Irarrazabal et al., 2015, and Appendix A). The mean unit value is exogenous by construction as it excludes the unit value to be instrumented. We also instrument the interaction terms involving unit values with the same interaction terms but with mean unit values.

The results are reported in Table C1. Column (1) reports OLS estimates, while in column (2) we instrument unit values and their interactions. Consistent with expectations, the coefficient $\Psi_{2}$ on the interaction between unit values and distance is positive, while the coefficient $\Psi_{4}$ on the triple interaction between unit values, distance, and quality is negative. Also, the coefficient $\Upsilon_{2}$ on the interaction between unit values and tariffs is negative, while the coefficient $\Upsilon_{4}$ on the triple interaction between unit values, tariffs, and quality is positive.

\footnotetext{
${ }^{29}$ Instead of quality, Irarrazabal et al. (2015) include a dummy variable for the high-price firms. Also, they only include a full set of interactions between unit values, distance, and the high-price firms dummy variable.

${ }^{30}$ If we include a full set of interactions between unit values, distance, tariffs, and quality, the coefficients on the interaction terms that involve both distance and tariffs are insignificant and our conclusions remain similar.
} 


\begin{tabular}{|c|c|c|}
\hline & $(1)$ & $(2)$ \\
\hline ln unit value & $\begin{array}{l}-15.209^{* * *} \\
(4.328)\end{array}$ & $-11.024^{* * *}$ \\
\hline quality & $\begin{array}{l}-0.124^{* *} \\
(0.061)\end{array}$ & $\begin{array}{c}-0.065 \\
(0.073)\end{array}$ \\
\hline ln unit value $\times$ quality & $\begin{array}{l}0.153^{* * *} \\
(0.046)\end{array}$ & $\begin{array}{l}0.106^{* *} \\
(0.046)\end{array}$ \\
\hline ln unit value $\times \ln$ distance $\left(\Psi_{2}\right)$ & $\begin{array}{l}2.115^{* * *} \\
(0.498)\end{array}$ & $\begin{array}{l}1.457^{* * *} \\
(0.494)\end{array}$ \\
\hline ln unit value $\times \ln$ tariffs $\left(\Upsilon_{2}\right)$ & $\begin{array}{l}-9.186^{* *} \\
(3.637)\end{array}$ & $\begin{array}{c}-6.173^{*} \\
(3.683)\end{array}$ \\
\hline ln distance $\times$ quality & $\begin{array}{l}0.019^{* * *} \\
(0.007)\end{array}$ & $\begin{array}{l}0.015^{*} \\
(0.009)\end{array}$ \\
\hline ln tariffs $\times$ quality & $\begin{array}{l}-0.233^{* * *} \\
(0.060)\end{array}$ & $\begin{array}{l}-0.177^{* * *} \\
(0.059)\end{array}$ \\
\hline ln unit value $\times \ln$ distance $\times$ quality $\left(\Psi_{4}\right)$ & $\begin{array}{l}-0.023^{* * *} \\
(0.005)\end{array}$ & $\begin{array}{l}-0.016^{* * *} \\
(0.006)\end{array}$ \\
\hline ln unit value $\times \ln$ tariffs $\times$ quality $\left(\Upsilon_{4}\right)$ & $\begin{array}{l}0.106^{* * *} \\
(0.040)\end{array}$ & $\begin{array}{l}0.068^{*} \\
(0.040) \\
\end{array}$ \\
\hline R-squared & 0.566 & 0.076 \\
\hline Observations & 87,078 & 58,646 \\
\hline Estimation & OLS & IV \\
\hline Kleibergen-Paap F & - & 178.76 \\
\hline
\end{tabular}

Notes: The dependent variable is the $\log$ FOB export volume (in liters). Firm-destination-time fixed effects are included. Robust standard errors adjusted for clustering by destination-time between parentheses. ${ }^{* * *},{ }^{* *}$, and ${ }^{*}$ indicate significance at the one, five, and ten percent levels. In (2), unit values (and their interactions) are instrumented with mean unit values (and their interactions).

The elasticities of $\epsilon^{f o b}$ with respect to distance and tariffs are given by:

$$
\begin{aligned}
\frac{\partial \epsilon^{f o b}}{\partial d i s t_{j}} \frac{\text { dist }_{j}}{\epsilon^{f o b}} & =\frac{1}{\epsilon^{f o b}}\left(\Psi_{2}+\Psi_{4} \times \text { quality }_{k}\right) \\
\frac{\partial \epsilon^{f o b}}{\partial t a r_{j, t}} \frac{t a r_{j, t}}{\epsilon^{f o b}} & =\frac{1}{\epsilon^{f o b}}\left(\Upsilon_{2}+\Upsilon_{4} \times \text { qualit }_{k}\right)
\end{aligned}
$$

To determine the sign and the magnitude of the two expressions, both for lower and for higher quality exports, we use the estimates reported in Table $\mathrm{C} 1$ and we rely on equation $(\mathrm{C} 2)$ to calculate $\epsilon^{f o b}$ at the $5^{t h}$ and $95^{t h}$ percentiles of the quality distribution (using the mean values of log distance and tariffs in our sample).

Based on the OLS estimates of column (1), the elasticity of $\epsilon^{f o b}$ with respect to distance is equal to $-0.454,-1.416$, and -0.098 at the mean, $5^{\text {th }}$, and $95^{\text {th }}$ percentiles of the quality distribution. The elasticity of $\epsilon^{f o b}$ with respect to tariffs is equal to 0.346 at the mean value of quality, and falls from 3.349 at the $5^{\text {th }}$ percentile to -0.761 (and therefore turns negative) at the $95^{\text {th }}$ percentile.

Using the IV estimates of column (2), the elasticity of $\epsilon^{f o b}$ with respect to distance is equal to $-0.137,-0.280$, and -0.033 at the mean, $5^{\text {th }}$, and $95^{\text {th }}$ percentiles of the quality distribution, while the elasticity of $\epsilon^{f o b}$ with respect to tariffs is equal to $0.445,1.037$, and 0.012 , respectively. The elasticity of $\epsilon^{f o b}$ with respect to distance is therefore negative and increases with quality. Instead, the elasticity of $\epsilon^{f o b}$ with respect to tariffs is positive and decreases with quality. 


\section{Selection Bias across Firms}

To remove selection bias across firms, we implement the three-step estimator of Harrigan et al. (2015). We construct a balanced sample of all possible firm-wine-destination-time combinations that includes positive and zero trade flows, and for each wine we drop the years prior to its vintage year.

In a first step we estimate the probability of entry using a reduced-form probit:

$$
\operatorname{pr}\left(x_{i j k, t}>0\right)=\Phi\left(\delta_{1} \ln Y_{j, t}+D_{k, t}\right)
$$

where $x_{i j k, t}$ is the export value, $Y_{j, t}$ includes distance, tariffs, GDP, GDP per capita, and remoteness (distance and tariffs can also be interacted with quality), and $D_{k, t}$ are product-time fixed effects. From equation (D1) we obtain the estimated inverse Mills ratio $\widehat{\lambda}_{i j k, t}$. In a second step we estimate by OLS a regression for positive export values with $\widehat{\lambda}_{i j k, t}$ included as an additional regressor:

$$
\ln x_{i j k, t}=\gamma_{1} \ln Y_{j, t}+\gamma_{2} \widehat{\lambda}_{i j k, t}+D_{k, t}+\epsilon_{i j k, t}
$$

and we calculate the quasi-residuals $\widehat{\kappa}_{i j k, t}=\widehat{\gamma}_{2} \widehat{\lambda}_{i j k, t}+\widehat{\epsilon}_{i j k, t}=\ln x_{i j k, t}-\widehat{\gamma}_{1} \ln Y_{j, t}-\widehat{D}_{k, t}$. In the final step we add $\widehat{\kappa}_{i j k, t}$ as a selection control in the regression for unit values:

$$
\ln u v_{i j k, t}=\zeta_{1} \ln Y_{j, t}+\zeta_{2} \widehat{\kappa}_{i j k, t}+D_{k, t}+\varrho_{i j k, t}
$$

Equations (D1) and (D2) are estimated separately for each wine (and, therefore, only include time fixed effects), while equation (D3) is regressed on the pooled sample including all wines. ${ }^{31}$

The results of the three-step selection correction procedure, with third-stage standard errors clustered by destination-time, are reported in Table D1. ${ }^{32}$ The samples are slightly smaller compared to the ones we use for our main regressions because some first-stage probit regressions fail to converge.

In all columns, the positive coefficient on the selection control implies that the correlation between the errors of the export price and of the export value regressions is around four percent. As explained by Harrigan et al. (2015), a positive correlation suggests that destination-specific demand shocks are likely to be more important than supply shocks in explaining which markets firms decide to enter. But most importantly, controlling for selection yields results which are both economically and statistically similar to our benchmark findings. Whether we measure distance as a continuous variable or using interval dummy variables, markups increase with bilateral distance, remoteness, and the destination's income per capita, and decrease with tariffs and country size (columns 1 and 2). In column (1), a doubling of distance induces an exporter to increase its markup by 2.3 percent on average.

\footnotetext{
${ }^{31}$ The estimates of the probit regressions (D1) may be biased due to the inclusion of time fixed effects. To address this issue we also estimated equations (D1) and (D2) separately for each wine in each quarter. Our results remain similar.

${ }^{32}$ Due to the firm-destination-time fixed effects, controlling for selection in equation (15) is computationally infeasible as this would require us to estimate the first-step probit using our full sample with more than 700,000 fixed effects included.
} 
Table D1: Selection Bias

\begin{tabular}{|c|c|c|c|}
\hline & (1) & $(2)$ & $(3)$ \\
\hline ln distance & $\begin{array}{l}0.033^{* * *} \\
(0.006)\end{array}$ & - & $\begin{array}{l}0.535^{* * *} \\
(0.070)\end{array}$ \\
\hline $2,900<$ distance $<7,700$ & - & $\begin{array}{l}0.045^{* * *} \\
(0.009)\end{array}$ & - \\
\hline $7,700<$ distance $<14,200$ & - & $\begin{array}{l}0.071^{* * *} \\
(0.014)\end{array}$ & - \\
\hline distance $>14,200$ & - & $\begin{array}{l}0.080^{* * *} \\
(0.017)\end{array}$ & - \\
\hline ln distance $\times$ quality & - & - & $\begin{array}{l}-0.006^{* * *} \\
(0.001)\end{array}$ \\
\hline ln tariffs & $\begin{array}{l}-0.135^{* * *} \\
(0.035)\end{array}$ & $\begin{array}{l}-0.130^{* * *} \\
(0.031)\end{array}$ & $\begin{array}{l}-1.494^{* * *} \\
(0.449)\end{array}$ \\
\hline ln tariffs $\times$ quality & - & - & $\begin{array}{l}0.016^{* * *} \\
(0.005)\end{array}$ \\
\hline ln remoteness & $\begin{array}{l}0.046^{* * *} \\
(0.011)\end{array}$ & $\begin{array}{l}0.041^{* * *} \\
(0.011)\end{array}$ & $\begin{array}{l}0.046^{* * *} \\
(0.011)\end{array}$ \\
\hline $\ln \mathrm{GDP}$ & $\begin{array}{l}-0.017^{* * *} \\
(0.002)\end{array}$ & $\begin{array}{l}-0.016^{* * *} \\
(0.002)\end{array}$ & $\begin{array}{l}-0.017^{* * *} \\
(0.002)\end{array}$ \\
\hline ln GDP/cap & $\begin{array}{l}0.019^{* * *} \\
(0.006)\end{array}$ & $\begin{array}{l}0.014^{* *} \\
(0.006)\end{array}$ & $\begin{array}{l}0.019^{* * *} \\
(0.006)\end{array}$ \\
\hline selection control & $\begin{array}{l}0.044^{* * *} \\
(0.007)\end{array}$ & $\begin{array}{l}0.043^{* * *} \\
(0.008)\end{array}$ & $\begin{array}{l}0.044^{* * *} \\
(0.007)\end{array}$ \\
\hline R-squared & 0.785 & 0.784 & 0.785 \\
\hline Observations & 66,785 & 66,578 & 66,785 \\
\hline
\end{tabular}

Notes: The dependent variable is the log FOB unit value of exports (in US dollars per liter). Product-time fixed effects are included. Robust standard errors adjusted for clustering by destination-time between parentheses. ${ }^{* * *}$ and ${ }^{* *}$ indicate significance at the one and five percent levels. Estimates are obtained using the three-step procedure of Harrigan et al. (2015).

Column (3) shows that the effects of distance and tariffs on markups are smaller in magnitude for higher quality exports. At the mean, $5^{t h}$, and $95^{t h}$ percentiles of the quality distribution, the distance elasticity is equal to $0.035,0.071$, and 0.001 (which is insignificant), while the tariff elasticity is equal to $-0.140,-0.238$, and -0.047 (which is not significant). Our results are therefore robust to controlling for selection bias across firms. Harrigan et al. (2015) find that removing selection bias leads to slightly smaller coefficients on distance, but they also conclude that the difference is negligible. 


\section{E Estimation of Quality}

We follow Bernini and Tomasi (2015) who adapt the Khandelwal (2010) procedure to estimate the quality of exports at the firm-product-destination-time level. The quality of an exported product is the part of its market share in a destination country that is not explained by its price. We estimate:

$$
\ln S_{i j k, t}-\ln S_{j K, t}=\beta_{1} u v_{i j k, t}+\beta_{2} \ln n S_{i j k, t}+D_{j, t}+D_{i k}+\eta_{i j k, t}
$$

where $S_{i j k, t}$ is the market share of product $k$ exported by firm $i$ to country $j$ in period $t, S_{j K, t}$ is the market share of an "outside variety" $K, n S_{i j k, t}$ is the "nest share," $u v_{i j k, t}$ is the export unit value, and $D_{j, t}$ and $D_{i k}$ are destination-time and firm-product fixed effects. Robust standard errors are adjusted for clustering by destination-time.

We construct each variable as follows. First, using the export value $x_{i j k, t}$ (in US dollars) and quantity $q_{i j k, t}$ (in kilograms) of each 8-digit HS-level product $k$ exported by firm $i$ to destination $j$ in quarter $t$ between 2002Q1 and 2009Q4 (from Nosis), we calculate unit values $u v_{i j k, t}$ (in US dollars per kilogram). Second, we use annual frequency data between 2002 and 2009 from the BACI data set to calculate the outside variety share $S_{j K, t}$ as the share of non-Argentinean import quantities (in kilograms) in the total import quantities of country $j$ in a 6-digit HS-level product category $K$ (Bernini and Tomasi, 2015). ${ }^{33}$ We match the outside variety share (at annual frequency) with the quarterly data from Nosis by year to calculate the market share $S_{i j k, t}$ and the nest share $n S_{i j k, t}$ as:

$$
\begin{aligned}
S_{i j k, t} & =\frac{q_{i j k, t}}{\sum_{i} q_{i j K, t} /\left(1-S_{j K, t}\right)}, \\
n S_{i j k, t} & =\frac{q_{i j k, t}}{\sum_{i} q_{i j k, t} /\left(1-S_{j K, t}\right)},
\end{aligned}
$$

where $q_{i j k, t}$ and $q_{i j K, t}$ are defined at the 8-digit and 6-digit HS levels (the denominators of E2 and E3 are proxies for each HS-level market size).

To address the endogeneity of unit values and of the nest shares, we use the Nosis data to construct the same instruments as Bernini and Tomasi (2015). We instrument unit values with the mean unit value of each 8-digit HS-level product by destination-time, and the nest shares with the number of 8digit HS-level products by firm-destination-time. We estimate equation (E1) separately for each 2-digit HS-level category. The quality of product $k$ exported by firm $i$ to country $j$ in period $t$ is obtained as:

$$
\text { quality }_{i j k, t}=\widehat{D}_{j, t}+\widehat{D}_{i k}+\widehat{\eta}_{i j k, t}=\left[\ln S_{i j k, t}-\ln S_{j K, t}\right]-\left[\widehat{\beta}_{1} u v_{i j k, t}+\widehat{\beta}_{2} \ln n S_{i j k, t}\right] .
$$

This procedure allows us to estimate the quality of each 8-digit HS-level product exported by each firm to each destination country between 2002Q1 and 2009Q4. We also follow the same approach in Section 6 to estimate the quality of wine exports.

\footnotetext{
${ }^{33}$ The BACI data set reconciles the declarations of importers and exporters reported in UN Comtrade (Gaulier and Zignago, 2010). The data are disaggregated at the 6-digit HS level.
} 


\section{F Robustness}

Table F1: Robustness on Samples and Specifications

\begin{tabular}{|c|c|c|c|c|c|c|c|}
\hline & (1) & $(2)$ & (3) & (4) & $(5)$ & $(6)$ & (7) \\
\hline ln distance $\times$ quality & $\begin{array}{c}-0.004^{* * *} \\
(0.001)\end{array}$ & $\begin{array}{l}-0.004^{* * *} \\
(0.001)\end{array}$ & $\begin{array}{l}-0.003^{* * *} \\
(0.001)\end{array}$ & $\begin{array}{l}-0.003^{\text {*** }} \\
(0.001)\end{array}$ & $\begin{array}{l}-0.003^{* * *} \\
(0.001)\end{array}$ & $\begin{array}{l}-0.005^{* * *} \\
(0.001)\end{array}$ & $\begin{array}{l}-0.004^{* * *} \\
(0.001)\end{array}$ \\
\hline ln tariffs $\times$ quality & $\begin{array}{l}0.028^{* * *} \\
(0.004)\end{array}$ & $\begin{array}{l}0.033^{* *} \\
(0.013)\end{array}$ & $\begin{array}{l}0.027^{* * *} \\
(0.004)\end{array}$ & $\begin{array}{l}0.025^{* * *} \\
(0.004)\end{array}$ & $\begin{array}{l}0.024^{* * *} \\
(0.004)\end{array}$ & $\begin{array}{l}0.023^{* * *} \\
(0.006)\end{array}$ & $\begin{array}{l}0.026^{* * *} \\
(0.004)\end{array}$ \\
\hline ln export volume & - & - & - & - & $\begin{array}{l}0.088^{* *} \\
(0.040)\end{array}$ & - & - \\
\hline ln export volume $\times$ quality & - & - & - & - & $\begin{array}{l}-0.001^{* *} \\
(0.000)\end{array}$ & - & - \\
\hline Observations & 67,105 & 56,605 & 64,884 & 63,743 & 66,941 & 53,197 & 71,466 \\
\hline Sample & Retailers & Full & $>2002$ & Ports & Full & Annual & Less 4.51 \\
\hline Estimation & OLS & IV & OLS & OLS & OLS & OLS & OLS \\
\hline
\end{tabular}

Notes: The dependent variable is the $\log$ FOB unit value of exports (in US dollars per liter). Robust standard errors adjusted for clustering by destination-time between parentheses. ${ }^{* *}$ and ${ }^{* *}$ indicate significance at the one and five percent levels. Firm-product-time and firm-destination-time fixed effects are included in (1). Product-time and firm-destinationtime fixed effects are included in (2) to (7). In (2), the interaction between tariffs and quality is instrumented with (log) total wine production interacted with quality. In (6), the time dimension for the fixed effects and the clustering is annual. To save space, the R-squared are not reported but are available upon request.

Table F2: Robustness on Quality

\begin{tabular}{|c|c|c|c|c|c|c|c|c|}
\hline & (1) & $(2)$ & $(3)$ & (4) & $(5)$ & (6) & $(7)$ & (8) \\
\hline ln distance $\times$ quality & $\begin{array}{l}-0.007^{* * *} \\
(0.002)\end{array}$ & $\begin{array}{l}-0.019^{* * *} \\
(0.004)\end{array}$ & )$_{(0.001)}^{-0.004^{* * *}}$ & )$_{(0.001)}^{-0.003^{* * *}}$ & $\begin{array}{l}-0.009^{* * *} \\
(0.003)\end{array}$ & - & )$_{(0.001)}^{-0.003^{* * *}}$ & - \\
\hline ln tariffs $\times$ quality & $\begin{array}{l}0.046^{* * *} \\
(0.011)\end{array}$ & $\begin{array}{l}0.113^{* * *} \\
(0.018)\end{array}$ & $\begin{array}{l}0.027^{* * *} \\
(0.004)\end{array}$ & $\begin{array}{l}0.020^{* * *} \\
(0.004)\end{array}$ & $\begin{array}{l}0.061^{* * *} \\
(0.015)\end{array}$ & - & $\begin{array}{l}0.028^{* * *} \\
(0.004)\end{array}$ & - \\
\hline ln distance $\times$ quality $^{e}$ & - & - & - & - & - & $\begin{array}{c}-0.025^{* * *} \\
(0.010)\end{array}$ & $\begin{array}{c}-0.029^{* *} \\
(0.014)\end{array}$ & - \\
\hline ln tariffs $\times$ quality $^{e}$ & - & - & - & - & - & $\begin{array}{l}0.119^{* * *} \\
(0.037)\end{array}$ & $\begin{array}{l}0.127^{*} \\
(0.073)\end{array}$ & - \\
\hline quality $^{e}$ & - & - & - & - & - & $\begin{array}{l}0.200^{* *} \\
(0.087)\end{array}$ & $\begin{array}{l}0.213^{*} \\
(0.111)\end{array}$ & - \\
\hline ln distance $\times$ quality $^{L}$ & - & - & - & - & - & - & - & $\frac{-0.003^{* *}}{(0.001)}$ \\
\hline ln distance $\times$ quality $^{H}$ & - & - & - & - & - & - & - & $\frac{-0.003^{* *}}{(0.001)}$ \\
\hline $\ln$ tariffs $\times$ quality $^{L}$ & - & - & - & - & - & - & - & $\begin{array}{l}0.042^{* * *} \\
(0.007)\end{array}$ \\
\hline $\ln$ tariffs $\times$ quality $^{H}$ & - & - & - & - & - & - & - & $\begin{array}{l}0.040^{* * *} \\
(0.006)\end{array}$ \\
\hline Observations & 33,448 & 66,941 & 66,813 & 57,113 & 33,448 & 125,112 & 64,713 & 66,941 \\
\hline Sample & Full & Full & No "Great" & No US & Full & Full & Full & Full \\
\hline Estimation & OLS & OLS & OLS & OLS & IV & OLS & OLS & OLS \\
\hline Quality & Parker & WS $[1,6]$ & WS & WS & WS & Est. & Est./WS & WS \\
\hline
\end{tabular}

Notes: The dependent variable is the log FOB unit value of exports (in US dollars per liter). Robust standard errors adjusted for clustering by destination-time between parentheses. ${ }^{* *},{ }^{* *}$, and ${ }^{*}$ indicate significance at the one, five, and ten percent levels. Product-time and firm-destination-time fixed effects are included. "WS" refers to the Wine Spectator quality ratings. In (5), the Wine Spectator ratings are instrumented with the Parker ratings (both interacted with distance and tariffs). In (6) and (7), quality ${ }^{e}$ is estimated using the Khandelwal (2010) methodology (see Appendix E). "Est." indicates that quality is estimated. In (8), quality ${ }^{H}$ and quality ${ }^{L}$ indicate high and low quality, respectively. To save space, the R-squared are not reported but are available upon request. 
Table F3: Cross-Sectional Estimates

\begin{tabular}{ccccc}
\hline & ln distance & ln distance $\times$ quality & ln tariffs & ln tariffs $\times$ quality \\
\hline \hline Year 2002 & 0.159 & -0.001 & 1.815 & -0.021 \\
& $(0.269)$ & $(0.003)$ & $(1.132)$ & $(0.014)$ \\
Year 2003 & 0.356 & -0.004 & -0.605 & 0.005 \\
Year 2004 & $(0.328)$ & $(0.004)$ & $(2.090)$ & $0.045^{* * *}$ \\
Year 2005 & $0.951^{* * *}$ & $-0.011^{* * *}$ & $-3.812^{* * *}$ & $(0.012)$ \\
(0.195) & $0.655^{* * *}$ & $-0.002)$ & $-2.866^{* * *}$ & $0.033^{* * *}$ \\
Year 2006 & $(0.166)$ & $(0.002)$ & $(0.931)$ & $(0.011)$ \\
Year 2007 & $0.310^{* *}$ & $-0.004^{* *}$ & $-1.943^{* * *}$ & $0.022^{* * *}$ \\
Year 2008 & $(0.153)$ & $(0.002)$ & $-2.069^{* *}$ & $(0.008)$ \\
Year 2009 & $0.382^{* * *}$ & $-0.004^{* * *}$ & $(0.845)$ & $0.023^{* *}$ \\
& $(0.118)$ & $-0.001)$ & $-2.202^{* *}$ & $(0.010)$ \\
Observations & $0.337^{* *}$ & $(0.002)$ & $-2.374^{* *}$ & $0.024^{* *}$ \\
\hline
\end{tabular}

Notes: The dependent variable is the log FOB unit value of exports (in US dollars per liter). Product-time fixed effects are included. Robust standard errors adjusted for clustering by destination-time between parentheses. ${ }^{* *}$ and ${ }^{* *}$ indicate significance at the one and five percent levels. GDP, GDP per capita, and remoteness are included but not reported. 